\title{
Technical, Economical, and Environmental Feasibility of Hybrid Renewable Electrification Systems for off-Grid Remote Rural Electrification Areas for East Azerbaijan Province, Iran
}

\author{
Khalil Aghapouramin ${ }^{1}$ (D) \\ Received: 14 May 2018 / Accepted: 5 October 2020 / Published online: 22 October 2020 \\ (C) Springer Nature Singapore Pte Ltd. 2020
}

\begin{abstract}
Nowadays, global warming, air pollution emissions, climate change, and fuel price growth are chronic challenges on a global scale for residential sectors. To overcome this, renewable energy systems would certainly be a potential alternative. Expanding electricity to remote rural areas with no access to grid electricity is a significant concern in the Middle East countries such as northern west of Iran. Off-grid hybrid renewable energy systems (RES) can be an ideal solution for remote rural areas no access is available to grid electricity. This research investigates the application of wind turbine, PV panels, and diesel generator in a hybrid renewable energy system for six off-grid remote villages, with separate locations and various climate statues, for East Azerbaijan province, Iran. Hybrid renewable energy system applies optimal size of several environmentally-friendly sources via HOMER software. In this study, for offering suitable configuration, all possible configurations of the renewable energy system were formulated for each village. These communities were chosen based upon Iran's Sixth Five-Year Economic and Renewable Energy Development Plan (2017-22). Wind speed and solar radiation data were extracted from Surface Meteorology and Solar Energy Dataset of NASA. For achieving accurate data on wind speed and solar radiation, as well as population for each community, they were extracted from Iran's Atlas and National Department of Statistics respectively. In order to explore the most cost-effective and efficient design for each community, various models of wind turbine, PV panels, and diesel generator were designed and optimized. In this study, most important economic indicators including initial capital (\$), operating cost (\$/yr), total NPC $(\$)$, and cost of energy $(\$ / \mathrm{kwh})$ were taken into account. For conducting economic and environmental sustainability, HOMER software was applied. For economic modelling and geographical position, Visio and Arc GIs software were used respectively.
\end{abstract}

Keywords HOMER software · Off grid remote rural areas · Renewable energy systems · Economic and environmental feasibility

\section{Introduction}

With renewable energy resources progressively becoming popular universally, environmental crisis and global warming are still considerable challenges [1]. The main prevalent environmental crises include pollution, resource evacuation, global warming, and environmental degradation. Environmental

Khalil Aghapouramin

Khalil.aghapouramin@gmail.com

1 Department of Mechanical Engineering, Faculty of Engineering, Eastern Mediterranean University, (Via Mersin 10) Famagusta TRNC, Turkey crises are detrimental effects by man-made activity on the biophysical environment. Environmental devastation imposed by human beings is a universal, continuous difficulty. The human effects on land can be viewed in different ways. The significant one is the temperature elevation and global warming which have been present for 50 years, mostly due to human activities (https://en.wikipedia.org/wiki/List_of power_stations_in_Iran).

In the past years, the technology of wind and solar energies has potentially advanced [2, 3]. Among Middle East countries, Iran has the largest energy usage by about $80 \%$ of Middle East upper average (https://financialtribune.com/ articles/energy/57299/iran-plans-to-boost-trifling-share-ofclean-energy) [4]. With Iran housing immense non-renewable sources, wind and solar energies are exceptionally welcomed 
with a great potential [5]. Overall, Iran is a best possible location for exploitation of solar and wind energy by enjoying high solar irradiation. Based upon Iran's Sixth Five-Year Economic Development Plan (2017-22) for renewable energy sources, case study communities have been chosen (https:// www.lexology.com/library/detail.aspx?g=9a25e9cc-44d045fa-9a54-905de434fc66). Most recent data have been gathered from Iran's Statistic division for modeling improvement (http://ostan-as.gov.ir/Page/16/\%D8\%A2\% D9\%85\%D8\%A7\%D8\%B1-\%D9\%88 \%D8\%A7\%D8\% B7\%D9\%84\%D8\%A7\%D8\%B9\%D8\%A7\%D8\%AA-\% D8\%A7\%D8\%B3\%D8\%AA\%D8\%A7\%D9\%86.html).

Based upon previous studies, there was a gap to be resolved by this study. Although different economic research has carried out for remote stand-alone hybrid electrification systems with DG, wind, and PV, their authors did not simultaneously and comprehensively perform economic and environmental feasibility study for one single province for stand-alone rural regions especially for northwest of Iran. The principal purpose of the current research is to study 6 standalone villages in East Azerbaijan province, Iran to explore the best composition of existing renewable energy systems. The research was performed through HOMER software. Furthermore, net present cost (NPC), cost of energy COE $(\$ / \mathrm{kWh})$, and initial capital were regarded as the optimization metrics.

The current study explores the application of PV panels, wind turbine, and diesel generator in a hybrid RES for six offgrid remote villages, with different location and diverse climate conditions, for East Azerbaijan province, Iran. In this research, all possible arrangements of RES were checked for each village. These communities have been selected based on Iran's Sixth Five-Year Economic and Renewable Energy Development Plan (2017-22). Solar radiation and wind speed data were extracted from Surface Meteorology and Solar Energy Dataset of NASA. In order to obtain precise data, solar radiation, population, and wind speed for each locality were obtained from Iran's Atlas and National Department of Statistics respectively. In this study, most significant economic indicators including total NPC (\$), initial capital (\$), cost of energy $(\$ / \mathrm{kwh})$, and operating cost $(\$ / \mathrm{yr})$ were taken into consideration to achieve an optimal design for each selected community. For economic and environmental sustainability, HOMER software was applied. For geographical location and economic model, Arc GIs and Visio software were used respectively.

\section{Literature Review}

Table 1 demonstrates most relevant literature review which performed in the last few years by researchers.

\section{Novelty and Work Comparison of the Present Research}

To the best knowledge of the authors, there is no comprehensive novel work on economic and environmental evaluation of PV/Wind/Diesel hybrid system in one single province. On the other hand, this novel research focused on economic and environmental investigation of one single province in order to find the best possible optimization for selected locations. Although various economical investigations have been performed for remote off-grid hybrid electrification systems with PV, Wind, and diesel generators, their authors did not simultaneously and comprehensively evaluate economic and environmental feasibility for one single province for off-grid rural areas especially for northwest of Iran. As some instances, the following studies have been performed over the past few years.

Barun K. Das et al. [18] studied techno-economic possibility of a stand-alone hybrid power generation for a remote region in Bangladesh. The suggested scheme incorporated a mix of PV, battery, wind turbines, biogas G, and DG to reach the load of electricity conditions via HOMER software. The fundamental purpose of this research is to conduct the feasibility study and environmental investigation of ordinary suburbs. Furthermore, a model for hybrid strategy implementation was recommended with relative benefits. The results showed that it is inconceivable to attain price parity of grid electricity even with complete aid of government for capital cost of research. Nonetheless, delivering electricity to the distant district with SHSs is an economical choice in relation to the suggested scheme.

Ramin Hosseinalizadeh et al. [19] investigated economic evaluation of small wind turbines in a residential section in Iran. In order to determine the most economic status for providing and analyzing the efficacy of various criteria, this research presented a general and united possibility evaluation of tiny wind turbines in 88 parts of Iran, applying the HOMER Software tool. The main purpose of this investigation was to deal with the shortcomings of the studied subjects. Other analyses in Iran concentrated on the feasibility reviews of one site or ultimately one part of the country and did not assess the wind energy of Iran on a macro scale. The outcomes demonstrated that small wind turbines are suitable almost in $30 \%$ of the considered areas. Further, FIT is one of the most efficient factors for suitable utilization of wind turbines.

Farivar Fazelpour et al. [20] focused on economic analysis of HE systems in Tehran, Iran, where PV - wind turbine - DG hybrid systems were examined in this research. Hydrogen was applied through DG to warrant a pure fuel is applied, contributing to a minimal environmental impact. Further, battery was employed in the system dependability evaluation. HOMER software was applied for the economic evaluation. The aim was to improve the energy utilization and reduce the 


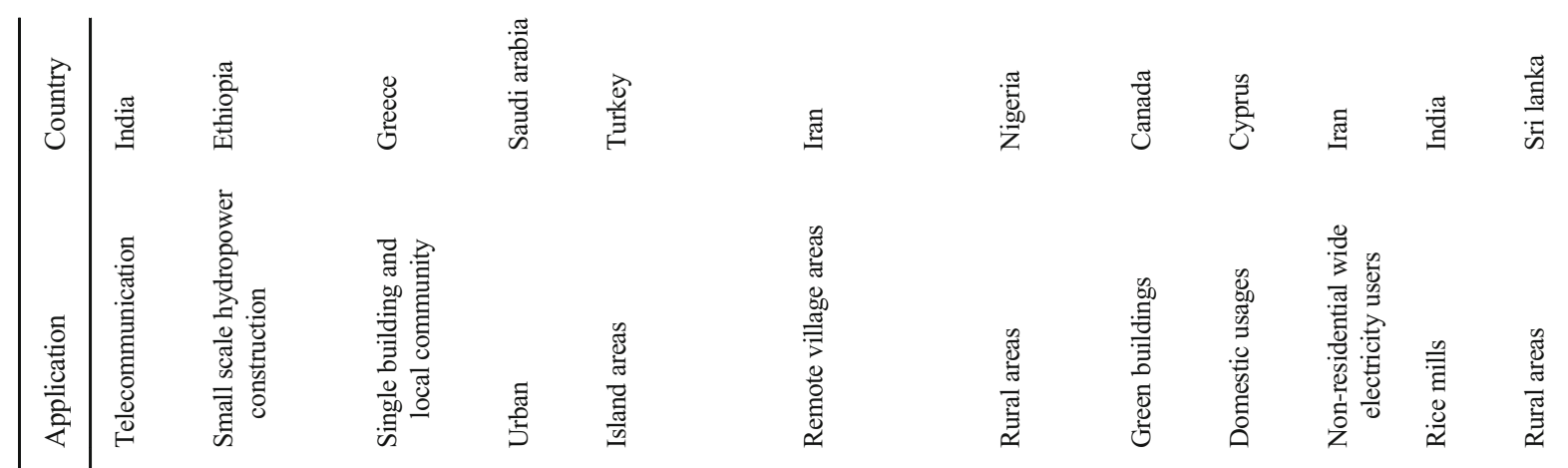

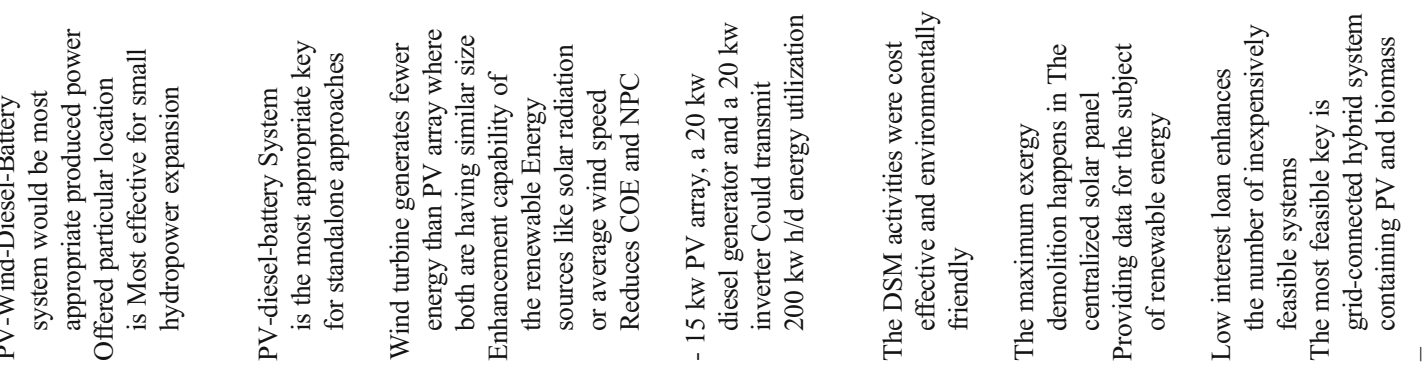

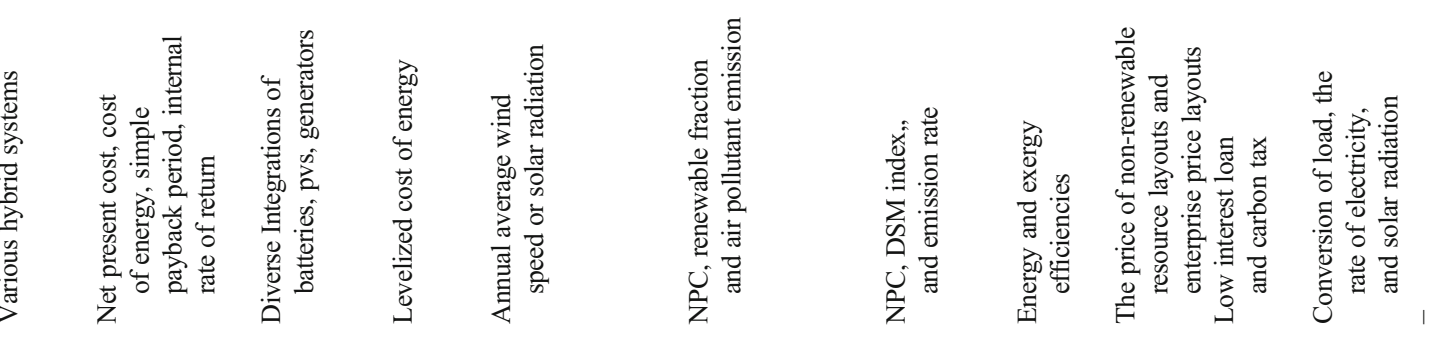

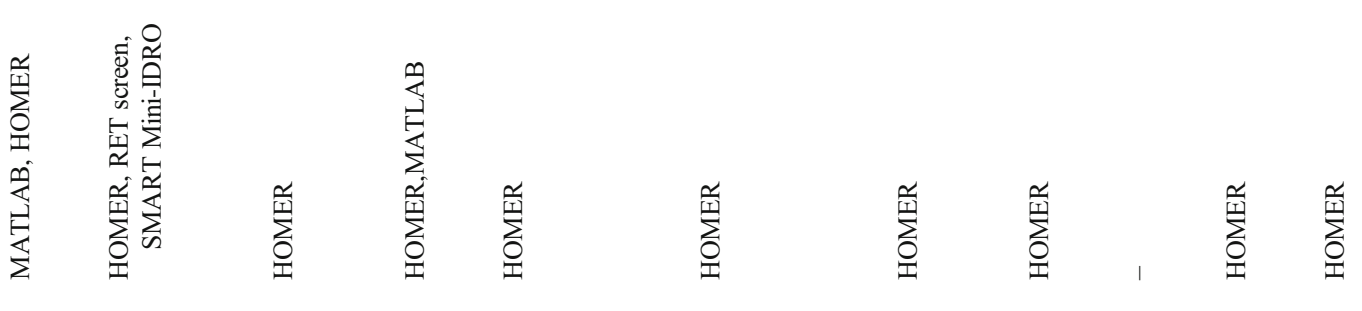

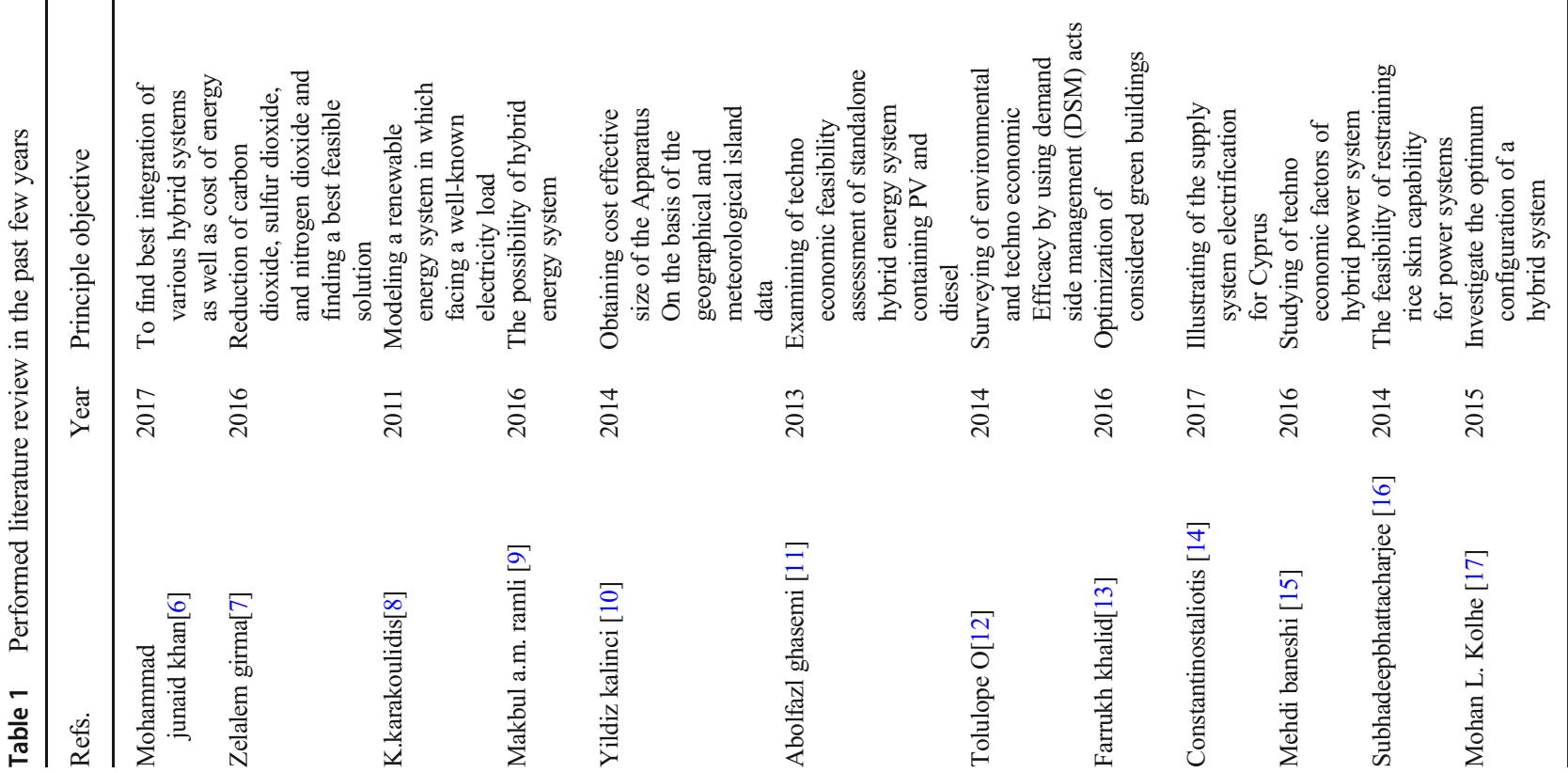


dependency on fossil fuels in domestic utilization by demonstrating the technical and economic possibilities correctly. The obtained results showed that amongst five hybrid systems, the most cost effective was the hydrogen-battery system which had a total NPC of US\$68,189 and COE of US $\$ 0.873 / \mathrm{kWh}$.

Luis Santiago Azuara Grande et al. [21] performed economic and environmental feasibility study of stand -alone PV-BESS for electric vehicles in Spain. For ascertaining the effectuality of the considered scheme, its performance was compared against grid electricity charging, in terms of environmental aspects. The primary objective was to achieve an economic goal for EVs, which assured the system performance, while being viable economically and technically. The results showed that off-grid PVBESS were economically reliable. In addition, they would allow a remarkable decline in air pollution.

Abdullah Al-Sharafi et al. [22] dealt with optimization and economic investigation of wind-solar systems for hydrogen production in Saudi Arabia. The purpose of this research was to explore the potentialities of power production and hydrogen generation through wind and solar energy across various regions in Saudi Arabia. These areas represented the climatic diversity with various wind speeds and solar radiation capabilities. At each site, various stand-alone renewable power production schemes were considered in order to cover the load demand of an ordinary household combining FC, wind turbine, battery, PV, converter, and electrolyzer. The final results indicated that the combination of three wind turbines, two $\mathrm{kW}$ converters, two $\mathrm{kW}$ PVs, as well as seven batteries was the best configuration offering minimal COE of 0.609 $\$ / \mathrm{kWh}$ at Yanbu region.

M. Kashif Shahzad et al. [23] concentrated on technoeconomic analysis of a stand-alone solar-biomass system for rural regions in Pakistan applying HOMER software. The fundamental objective of this research was to offer optimized configuration for electricity production applying hybrid Photovoltaic-Biomass for an agricultural plantation and a residentiary district placed in a small suburb in Pakistan. In order to handle the load conditions, HOMER was applied to design and carry out economic and technical evaluation applying Biomass-Photovoltaic hybrid system. The results showed that the system is economically feasible based upon the NPC and cost of energy.

Monotosh Das et al. [24] focused on techno-economic analysis of a stand-alone hybrid system applying metaheuristic methods in India. A sensibility investigation based upon loss of load possibility was performed to explore the possibility of the recommended model. The purpose of that research is to gain an economic and technical design of stand-alone hybrid battery-biogas G-PV system with the aid of metaheuristic methods for a radio site in India. The result indicated that both considered metaheuristics were useful in gaining the best design, though water cycle algorithm outperformed the others in design.
A. Can Duman et al. [25] studied the techno-economic feasibility of stand-alone PV-wind-fuel cell system compositions as compared to regular households. In that research, electrical energy usage of stand-alone vacation houses through FC-PV-wind turbine hybrid systems was examined from economic and technical viewpoints. Twenty-four various simulations were presented via HOMER software under different climatic statuses of Izmir, which has nearly high wind and solar energy for Turkey where vacation houses are placed. The results showed that the COE of stand-alone systems was above that of grid electricity but less than previous years.

\section{Problem Statement}

The number of households with available electricity grid in the East Azerbaijan province has been growing since 2011. In the East Azerbaijan province, there are 513,845 households with accessibility to the electricity grid. Although the remaining (12,846 individuals) does not have access to the electricity grid, over $75 \%$ have accessibility to renewable energy resources. Even though many remote rural regions in the East Azerbaijan province do not have access to the electricity, village electrification has developed over the past few years. Hence, applying wind turbines, diesel generators, and PV panels can be a rational solution for satisfying peak electrical demands as an alternative renewable clean energy for remote rural areas of East Azerbaijan province.

\section{Objectives of the Current Research}

The main objective of the present study is to investigate six off-grid villages in East Azerbaijan province, Iran with different locations and diverse climate conditions in order to choose the best compound of existing renewable energy systems for finally providing electricity demands in a reliable and sustainable way for each locality. In addition, the cost of energy $(\mathrm{COE})(\$ / \mathrm{kWh})$, initial capital, and net present cost (NPC) have been considered as the main optimization metrics.

\section{Iran's Current Renewable Energy Status}

The southern, northwestern, and southeastern parts enjoy the most suitable investment potential for solar energy exploitation with almost 300 sunny days each year (http://www.mei. edu/content/article/iran\%E2\%80\%99s-renewable-energypotential). The clean solar energy is used in many studies as it causes no greenhouse gas (GHG) emission and incurs lower maintenance costs. The details of solar energy were provided from Solar Energy and Surface Meteorology NASA. Based 
upon the available data of Power Ministry of Iran, renewable resources claim only less than $1 \%$ of the energy basket. Nonetheless, Iran is an official member of the International Renewable Energy Agency (IRENA). There were a few active private energy sectors established for expanding companies in various parts of Iran. These companies have been established to curb the greenhouse gas emissions. However, owing to independent subsidiaries, their goal would hardly be achieved efficiently. Generally, in Iran, due to considerable return on investment, the budgets of current wind energy projects are cost effective compared to solar energy projects. However, it can certainly solve the long-term persistent problems. Over the last decades, fossil fuels have been the significant primary material for power generation systems. Those power plants which are operating by natural gas, oil or mazut, causing extensive greenhouse gas emissions into the atmosphere. Iran has massive desert areas which can support the entire household electricity demand by providing 75,000 MW electricity. Lately, East Azerbaijan province was hosted by few private power generation companies in order to generate $50 \mathrm{MW}$ electricity.

\section{Geographic Characteristics of East Azerbaijan and its Population}

Tabriz is the capital of East Azerbaijan province. Based upon 2006 Statistical Center announcement, Tabriz, Maragheh, and Marand are the most populous cities of East Azerbaijan province respectively. More recently, the professional services of renewable energy technology under the organization of East Azerbaijan Academic Center for Education, Culture and Research (ACECR) have aimed for expansion and promotion of renewable energy utilization (http://tabriz.isna.ir/ default.aspx?NSID=5\&SSLID=46\&NID=93309). East Azerbaijan Province is located in northeast of Iran bordering Republic of Azerbaijan, West Azerbaijan Province, Ardabil Province, and Armenia with a population of about four million inhabitants (https://en.wikipedia.org/wiki/East_Azerbaijan Province\#cite_note-6). The province covers a region of nearly $47,830 \mathrm{~km}^{2}$. The highest spot of East Azerbaijan is Sahand Mountain at $3707 \mathrm{~m}$ of height located in the south of Tabriz, while the lowest area is Ahar. The mountains of the province have three separate segments named Qaflan Kooh Mountains, Sahand and Bozqoosh Mountains, and the Qara Daq Mountains. Cold semi-arid climate and Mediterranean Continental are playing an important role in the climate of East Azerbaijan. In Tabriz, temperature begins at around $8.9{ }^{\circ} \mathrm{C}$ and falls down to -10 to $-15^{\circ} \mathrm{C}$ in the winter. Obviously, overall air coldness has a direct effect on temperature. Hence, the spring and summer months are the most suitable time for visiting this province. East Azerbaijan Province had twelve counties by the 1986 . Two more counties called Jolfa and Malekan were established by the end of 1996. There were five more new divided counties namely, Osku, Azarshahr, Ajabshir, Varzagan, and Charoimaq established from 1996 to 2002. East Azerbaijan province is an important industrial section of Iran by possessing over 5000

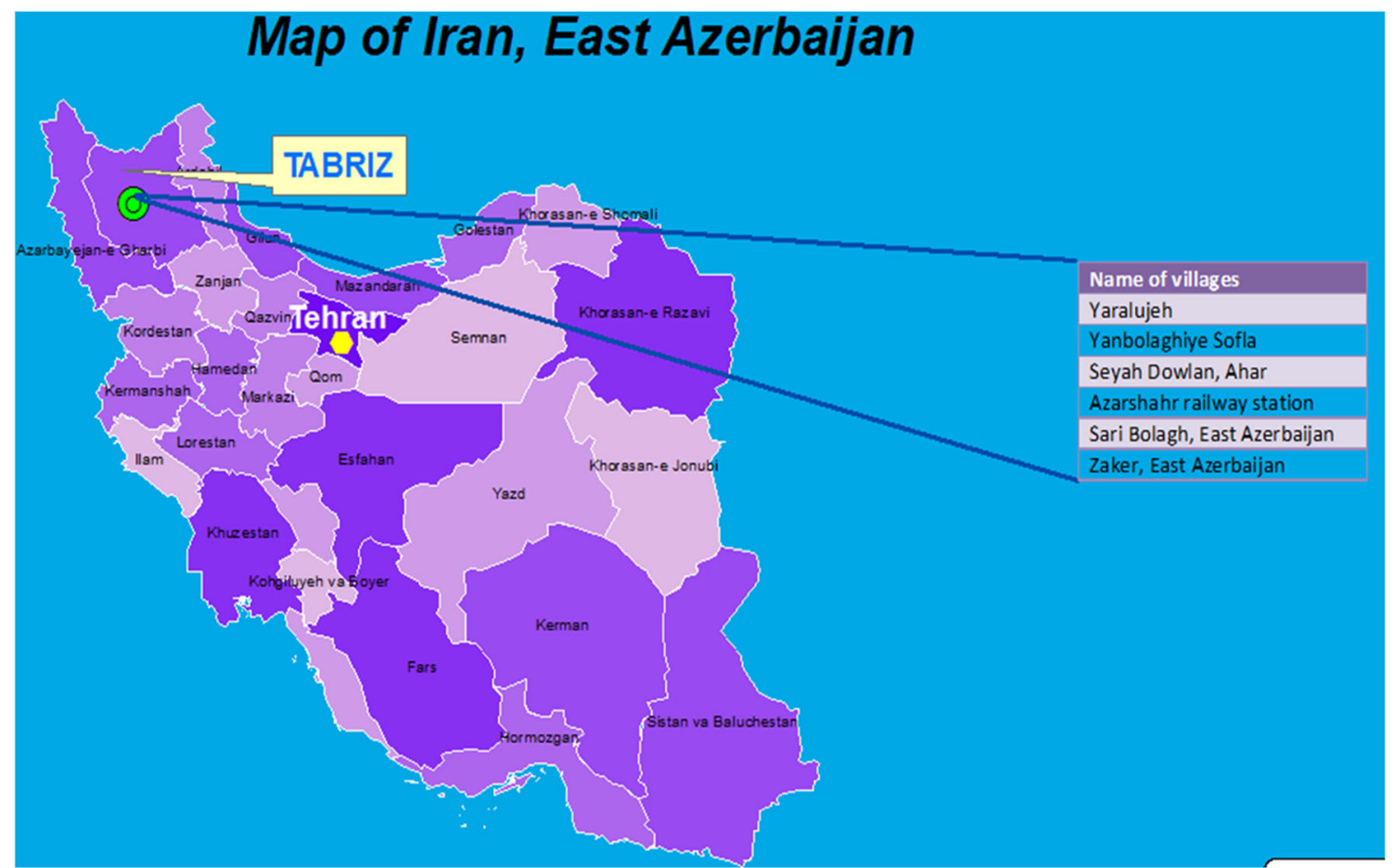

Fig. 1 Geographical position of proposed study areas 
manufacturing segments. East Azerbaijan's main industries include steel, oil refinery, chemical products, industrial machines, etc. East Azerbaijan has a wide range of handicrafts in Iran as well as a large percentage of exports. UNESCO has two origins named Arasbaran and Lake Urmia in East Azerbaijan province. Figure 1 demonstrates thee geographical station of the chosen communities. The number of households with available electricity grid in the East Azerbaijan province has been one the rise since 2011. In the East Azerbaijan province, there are 513,845 households with access to the grid covering 97.5\% of East Azerbaijan province population (https://en.wikipedia.org/wiki/East_Azerbaijan_Province). Even though remaining $2.5 \%$ (12,846 individuals) does not have access to the electricity grid, over $75 \%$ have accessibility to renewable energy resources. Many remote rural areas in the East Azerbaijan province do not have access to the electricity; however, village electrification has expanded over the past few years. Accordingly, usage of diesel generators, PV panels, and wind turbines can be a logical way for satisfying the peak electrical requests as alternative sources of clean renewable energy. Selected remote rural areas of this province include the following villages: Yaralujeh, Yanbolaghi-ye Sofla, Seyah Dowlan, Ahar, Azarshahr Railway Station, Sari Bolagh, East Azerbaijan, Zaker, East Azerbaijan. Yaralujeh is a small village located in the Kaleybar County. The selected villages represent low-income communities. These villages are geographically separated, and are climatically almost different. Based upon the current statistic, its population is 15 with 4 households. Yanbolaghi-ye Sofla is located in the Hashtrud County. Its population is 28 with 5 inhabitants. Table 2 summarizes the information about villages. Note that the data of available connected villages were issued from national department of statistics of Iran.

\section{Environment Pollution in the East Azerbaijan Province}

The most significant environmental crisis in this province is air pollution. The reasons behind this include contamination industries such as thermal power planets, oil refinery, and promotion of non-renewable energy consumer industries. The primary issue is the Lake Urmia located in the western border with Tabriz. There are three non-renewable energy consumer power plants in this providence including Bonab thermal power plant, Tabriz thermal Power Plant, and Sofian power plant. These power plants are functioning only with fossil sources which are associated with a lower efficiency and remarkable energy wastes plus environmental problems, air pollution, and health challenges.

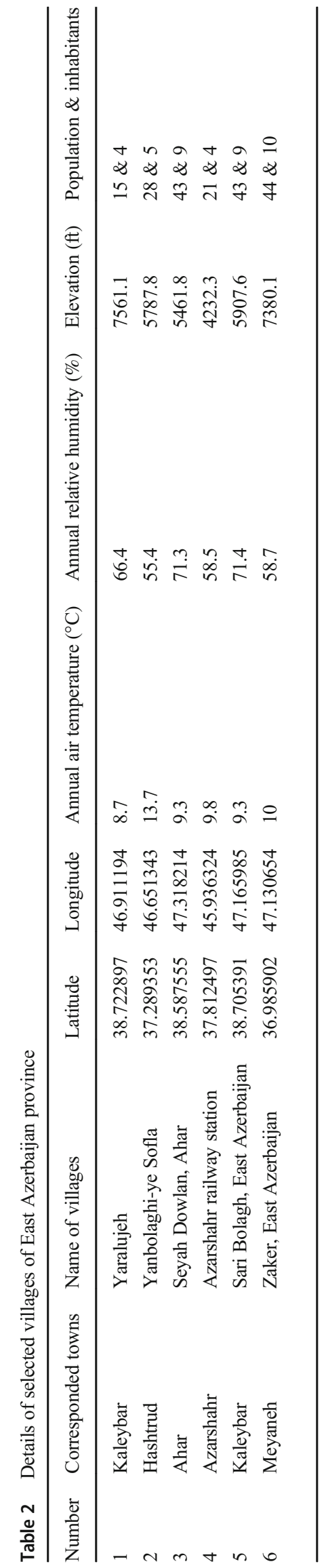




\section{Description}

The techno-economic feasibility of solar-wind hybrid system was studies by applying HOMER software. Although research has concluded that diesel utilization in a hybrid configuration of batteries, PVs, and diesel reduces the necessity of battery and has also a reliable origin, environmental contamination is still a serious issue for batteries.

\section{Load Estimation of the Selected Villages}

In order to calculate electricity demand and energy necessity for every single community, estimations made by previous studies were applied. The population of each community was also obtained from national department of statistics of Iran. The main portion of electrical loads is claimed by $400 \mathrm{~W}$ lighting, $1100 \mathrm{~W}$ refrigerator, $750 \mathrm{~W}$ various devices, etc. Table 3 reports the electrical demand of the principal components. Note that energy consumers are mainly housewives, students, and nurses. Since the economy of these villages is based on farming, thus active individuals are outside of the house especially in spring, summer, and early September. For computing the load profiles, in addition to households, two basic energy consumer centers were considered for each community. Indeed, one school and one small health center were considered with loads of $2850 \mathrm{~W}$ and $3110 \mathrm{~W}$ respectively. The health center electrical energy consumer equipment was considered to be fluorescent lights, computer and printer, suction, x-ray machine, vaccine refrigerator, hematology analyzer, and blood chemistry analyzer. The school was equipped with fluorescent lights, mobile phone charger, computer, printer, plus water pump. Air conditioning systems consumed remarkable amount of energy, and thus utilization of air conditioning systems would not be cost effective among lowincome communities. Although during the day, Azarshahr Railway Station's average temperature rises up to $32{ }^{\circ} \mathrm{C}$ during May-August, air conditioning systems are not utilized all day long. The daily electrical load profiles for the selected villages are shown in Fig. 2(a) - (f). As can be seen from these figures, electricity utilization has remarkably increased from July to September, from 10 AM to $8 \mathrm{PM}$, during the warm and cold

Table 3 Electricity demand of main equipment months of the year from May to August and May to September respectively. However, in the rest of months, electricity consumption is not as regular as in July to September. By applying geographic coordinates for East Azerbaijan, Iran, the monthly average wind speed and solar irradiation were obtained as indicated in Fig. 3(a) and (b) (https://www.distancesto.com/ coordinates/ir/tabriz-latitude-longitude/history/2964.html). For data accuracy, the resulting data were compared with Solar Energy and Surface Meteorology NASA.

\section{Principal Components}

The prices of major components were found via various producers. Concerning the components available on Iran's market, especially East Azerbaijan province, major components were selected. Therefore, the top components were chosen by considering the operation \& maintenance costs, further expenses, and lifetime.

\section{PV Array}

The PV array brings out direct current from solar energy as attachment of PV parts. In the current research, the PV array was considered as a base load power. The operating yielding power of PV array can be captured by HOMER software. It can be computed by the following equation.

$P_{P V}=f_{P V} Y_{P V} \frac{I_{T}}{I_{S}}$

- $f_{P V}$ is the derating factor of PV

- $Y_{P V}$ is the leveled capacity of PV array (KW)

- $I_{S}$ is the modulus value of radiation $(1 \mathrm{~kW} / \mathrm{m} 2)$

- $I_{T}$ is related to the global solar radiation, happening on the $\mathrm{PV}$ array surface $\left(1 \mathrm{KW} / \mathrm{m}^{2}\right)$

Various sizes of PV panels $(10,18,27,36,45,54,63,72,81$, $90,99,100,200,300,400$ and $500 \mathrm{~kW}$ ) are provided in this analysis.

\section{Converter}

Power converter is typically applying to sustain the energy flow from AC to DC.

\section{Battery}

Battery-charging master plans

The two main dissimilar master plans supplied through HOMER are load-following and cycle-charging. In cycle-charging tactics, batteries are typically charged 


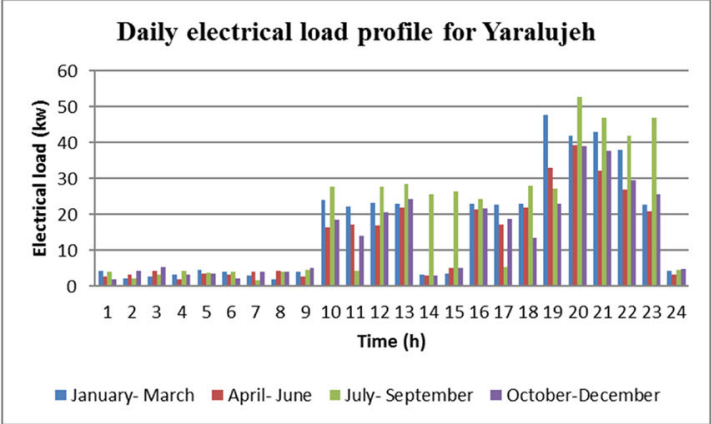

(a)

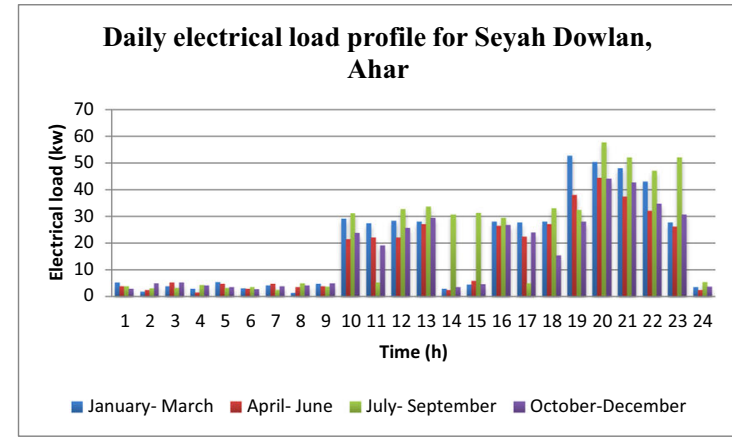

(c)

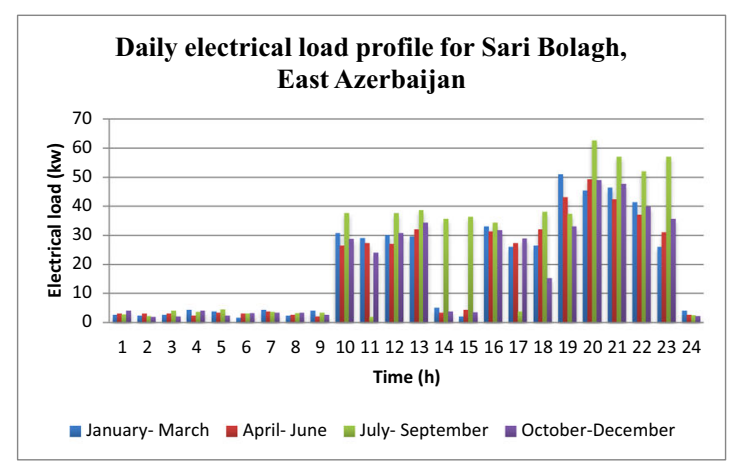

(e)

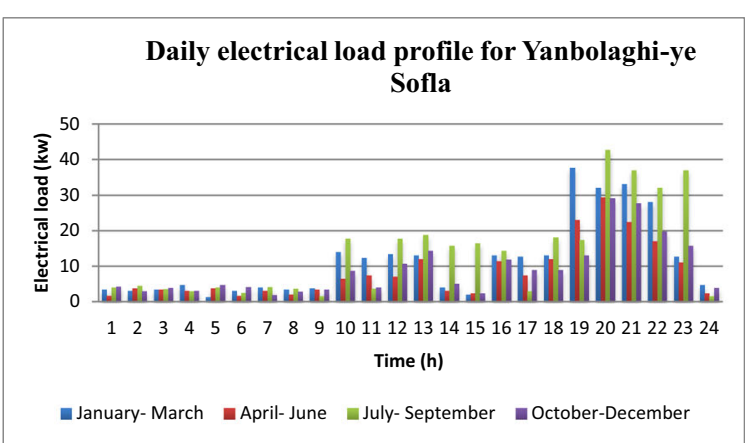

(b)

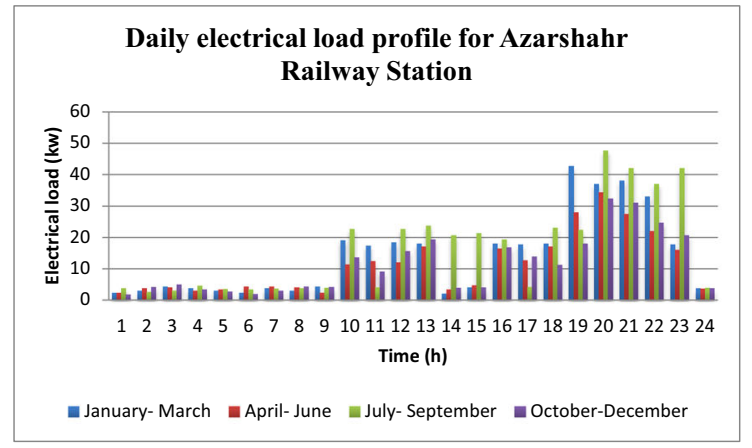

(d)

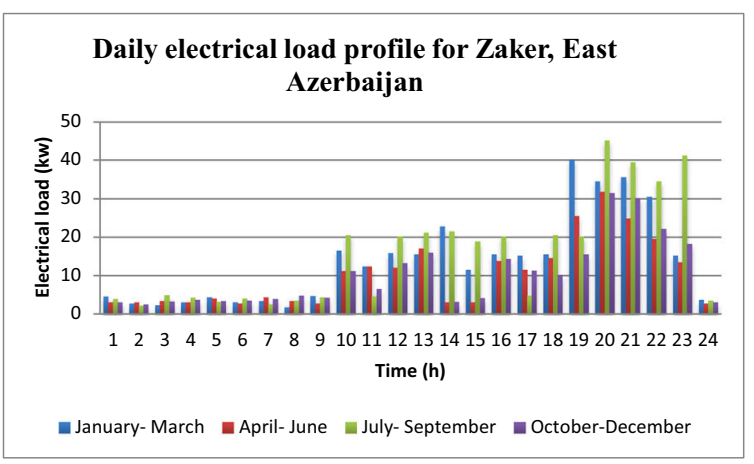

(f)

Fig. 2 a, f, daily electrical load profile for selected villages

with surplus electricity where the generator runs in its nominal power. From an opposing view, batteries host renewable sources while the generator yields merely the power which barely faces the demand load [26, 27]. In this study, the selected areas receive considerable wind energy and solar radiation every single year, therefore expanding the optimized electrification through a renewable energy system would be the principal strategy. A battery bank is typically applied in off-grid hybrid systems, and as such it was selected here. Generally, batteries are applied to lighten the mismatch between electricity production and load demands. By joining PV panels, batteries would be used like a storage system in order to diminish uncertainty and to increase the stability of the energy system. Chemical reactions provide the electrical power of the battery. During the responses, reactors of the battery start to function, while right after termination of a reaction, discharging should be applied. Table 4 reports the technical details of the battery. Different sizes of battery have been applied $(5,9,18,27,36,45,54,63,72,81,90,99,100,200$, $300,400,500)$.

\section{Diesel Generator}

The accurate size of diesel generator has to be considered, principally when the diesel generator and electrical load are connected to the same bus where the peak requested electric power could be obtained [28]. In the current study, a 10KW diesel generator was assumed. The replacement and capital costs of diesel generator were assumed to be $\$ 5000 / \mathrm{kW}$ and $\$ 6000 / \mathrm{kW}$ respectively. The operating hours of the generator 
Fig. 3 a, b, monthly average wind speed and solar radiation of selected villages

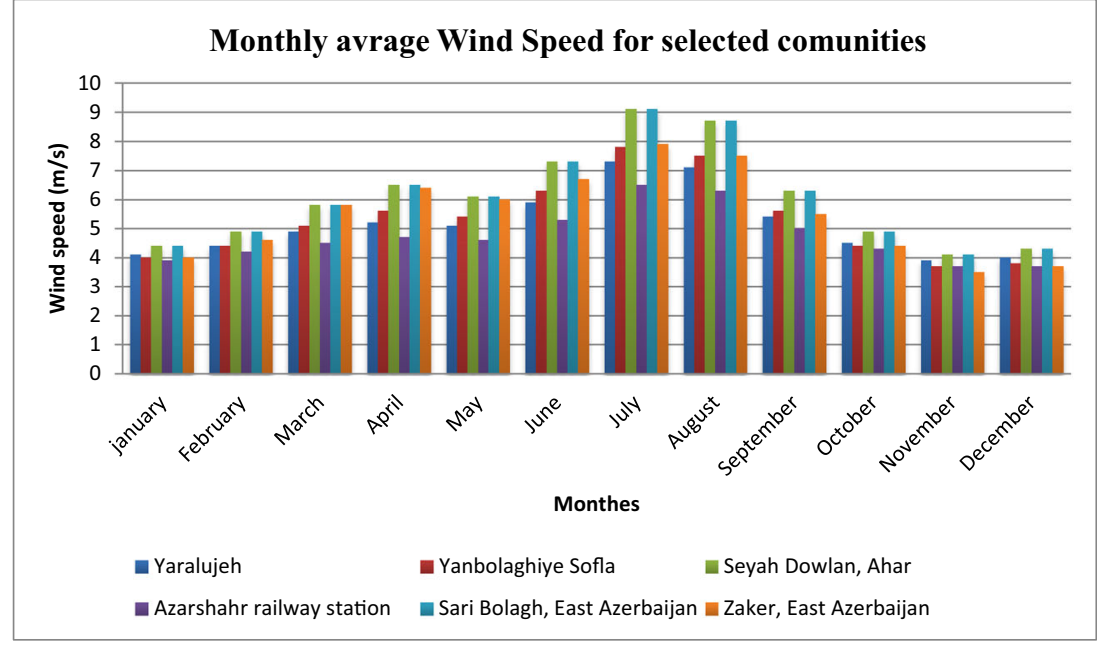

(a)

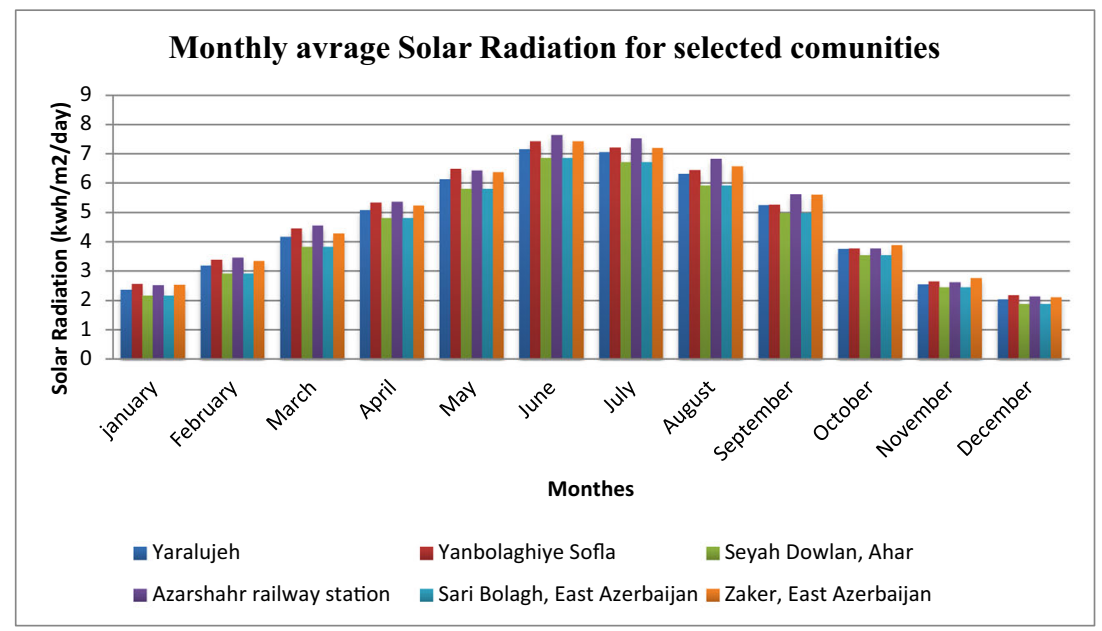

(b) were considered to be $85,000 \mathrm{~h}$ as life time. Based upon assumption, the operation and maintenance (O\&M) cost of the generator was considered to be $\$ 0.065 / \mathrm{h}$. Note that at the present time, Iran's diesel price is $\$ 0.5 / \mathrm{L}$. Various sizes of diesel generator were studied including $(9,18,27,36,45$, $54,63,72,81,90,99,100,200,300,400,500 \mathrm{kw})$.

\section{Wind Turbine}

In this study, wind turbine had a BWC Excel-S description. Furthermore, wind turbine with the abbreviation of XLS has a nominal power of $10 \mathrm{KW}$ AC. Table 4 outlines the technical details of the wind turbine. Because of energy efficiency expediency, wind turbine connected to the AC bus would not be necessary in this electricity transmission process. Figure 4 demonstrates the power curve of wind turbine. Capital cost, replacement, and operation and maintenance (O\&M) costs of wind turbine were assumed to be $\$ 27,378 / \mathrm{kW}, \$ 24,640 / \mathrm{kW}$, and $\$ 273 /$ yrs. Different sizes of wind turbine were analyzed including $(9,18,27,36,45,54,63,72,81,90,99,100,200$, 300,400 , and 500).

\section{Economic Model}

Wind turbines, PV panels, and diesel generators were taken into consideration as power suppliers. In this research, NPC, $\mathrm{COE}$, operating cost, and initial capital cost were taken into account as economic indicators. Figure 5 reveals these indicators along with their definition and correlated equation. As can be seen from Fig. 5, NPC is a feasible indicator compared to COE because of its mathematical model. Yearly $\mathrm{CO} 2$ emission is considered as major environmental indicator. In case the yearly optimized system is obtained, the environmental indicators such as $\mathrm{CO} 2$ emissions are calculated for each single system. Furthermore, yearly power generation for each single component can be easily obtained. 
Table 4 technical characteristics of selected components

\begin{tabular}{|c|c|c|c|}
\hline \multirow[t]{15}{*}{ Battery } & \multicolumn{2}{|l|}{ Description } & Surrette S4KS25P \\
\hline & \multicolumn{2}{|l|}{ Abbreviation } & S4KS25P \\
\hline & \multicolumn{2}{|l|}{ Manufacturer } & Rolls/ Surrette \\
\hline & \multicolumn{2}{|l|}{ website } & www.rollsbattery.com \\
\hline & \multicolumn{2}{|l|}{ Nominal capacity } & $1900 \mathrm{Ah}$ \\
\hline & \multicolumn{2}{|l|}{ Nominal voltage } & $4 \mathrm{~V}$ \\
\hline & \multicolumn{2}{|c|}{ Round trip efficiency } & $80 \%$ \\
\hline & \multicolumn{2}{|l|}{ Min. state of charge } & $40 \%$ \\
\hline & \multicolumn{2}{|l|}{ Float life } & $12 \mathrm{yrs}$ \\
\hline & \multicolumn{2}{|l|}{ Max. charge rate } & $1 \mathrm{~A} / \mathrm{Ah}$ \\
\hline & \multicolumn{2}{|l|}{ Max. charge current } & $67.5 \mathrm{~A}$ \\
\hline & \multicolumn{2}{|l|}{ Lifetime throughput } & $10,569 \mathrm{kwh}$ \\
\hline & \multicolumn{2}{|l|}{ Max. capacity } & $1887 \mathrm{Ah}$ \\
\hline & \multicolumn{2}{|l|}{ Capacity ratio, c } & 0.254 \\
\hline & \multicolumn{2}{|l|}{ Rate constant, $\mathrm{k}$} & $0.5281 / \mathrm{h}$ \\
\hline \multirow[t]{5}{*}{ Wind turbine } & \multicolumn{2}{|l|}{ Description } & BWC Excel-S \\
\hline & \multicolumn{2}{|l|}{ Abbreviation } & XLS \\
\hline & \multicolumn{2}{|l|}{ Rated power } & $10 \mathrm{KW} \mathrm{AC}$ \\
\hline & \multicolumn{2}{|l|}{ Manufacturer } & Bergey Windpower \\
\hline & \multicolumn{2}{|l|}{ website } & www.bergey.com \\
\hline \multirow[t]{6}{*}{ Diesel generator } & \multicolumn{2}{|c|}{ Intercept coeff (L/h/kw rated) } & 0.080 \\
\hline & \multicolumn{2}{|c|}{ Slope (L/h/kw rated) } & 0.25 \\
\hline & \multicolumn{2}{|l|}{ Heat recovery ratio } & 0 \\
\hline & Emissions factors & Carbon monoxide ( $\mathrm{g} / \mathrm{L}$ of fuel) & 6.5 \\
\hline & & Unburned hydrocarbons ( $\mathrm{g} / \mathrm{L}$ of fuel) & 0.72 \\
\hline & & Particulate matter ( $\mathrm{g} / \mathrm{L}$ of fuel) & 0.49 \\
\hline
\end{tabular}

\section{Methodology}

\section{HOMER Software}

The computer model software named Hybrid Optimization Model for Electric Renewable (HOMER) aims to simplify the assessment of design election duties. In this regard, both off-grid and grid connected systems would be in the evaluation circle for most forms of generation applications including stand alone, distributed, remote and so forth. This software is extended in the USA by the National Renewable Energy Laboratory (NREL) in 1993. The optimized algorithms perform a facile task for simplification in identifying the most economic system formations. Accordingly, existing sources, details of portions, cost of components, technology choices, and inputs of consumer load should be undoubtedly considered for a specific geography [29]. Hybrid power systems combined with formal generators, mixed power, battery banks, biomass, solar photovoltaic, wind turbines and other components can be simply simulated, analyzed and designed via this excellent modeling software. It is globally utilized by many individuals. Indeed, HOMER plays a pivotal role for obtaining combined optimal hybrid systems. Most professionals apply HOMER in order to analyze various energy systems, reconcile the outcomes, and more importantly achieve an optimized scheme. Homer can handle striking tasks including economic feasibility assessment, optimization of hybrid energy designed system, and facilitating the comprehension of the method for execution of hybrid renewable systems [30-32]. INSEL, Hybrid2, SOMES, iHOGA, and ARES software can be used for hybrid power system evaluation, though in this study we applied HOMER software. This software offers a generic evaluation for energy systems, and

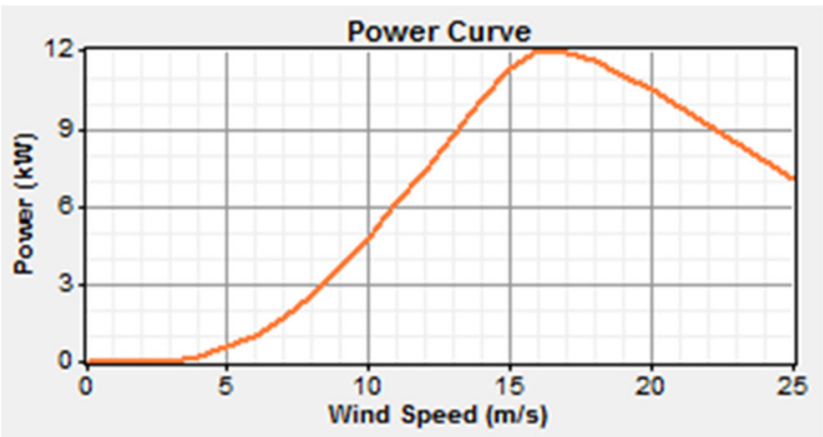

Fig. 4 Power curve of selected wind turbine 


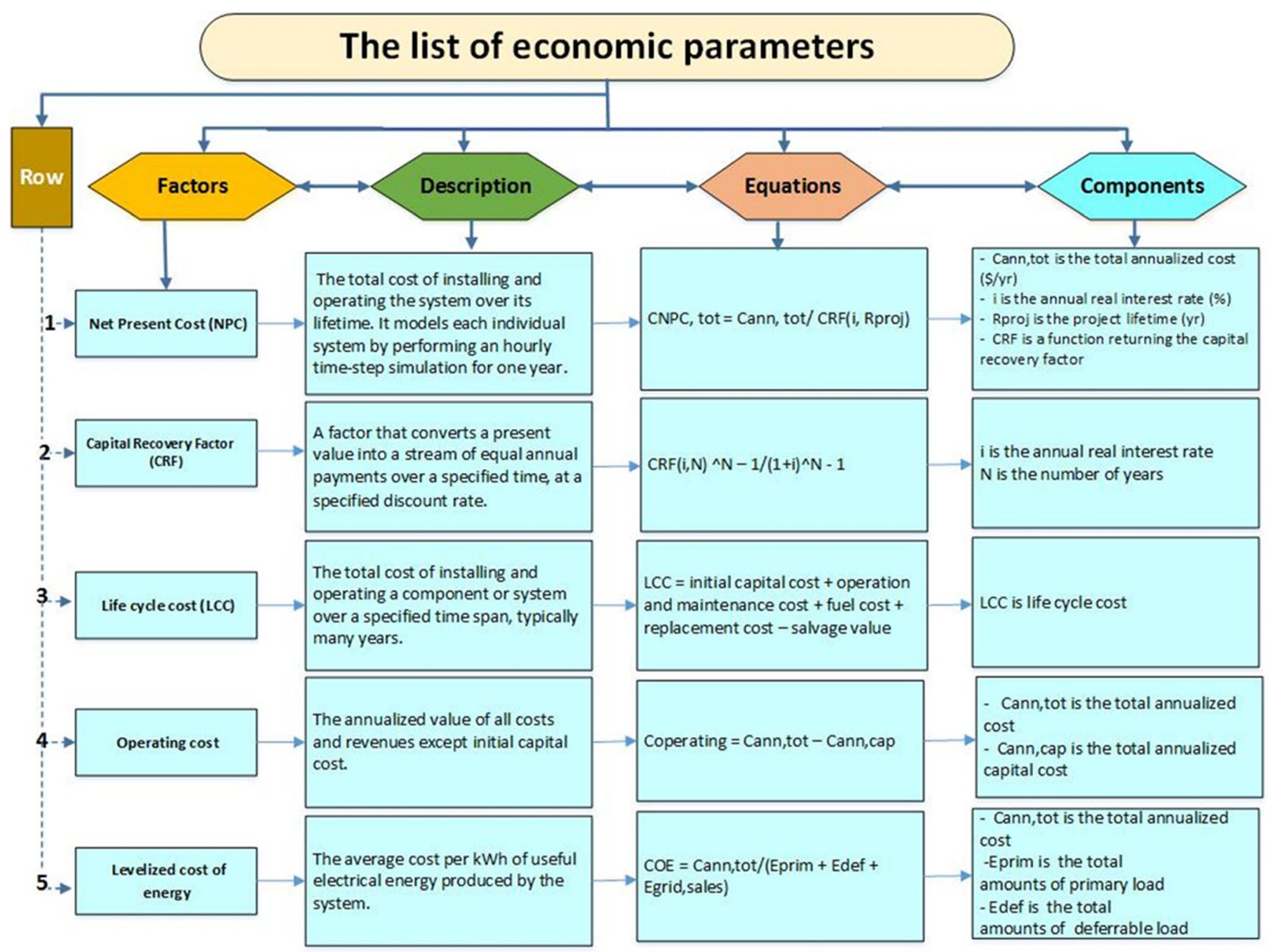

Fig. 5 Economic model of optimal systems

hybrid energy renewables can be employed using fuel cells and diesel generators. Note that HOMER is capable of performing analyses on various energy system components, with different dimensions. In the literature, many studies have used HOMER software to analyze feasibility parameters of hybrid energy systems. The simulation of HOMER is based upon load and meteorological date where load data should be on a monthly basis [33].

\section{Scenarios}

Economic optimization of various arrangements was performed by means of HOMER software for each community. The ultimate goals of this investigation include 1) to evaluate environmental, economical, and technical ability of all feasible arrangements of wind turbines, batteries, diesel generators, and PV panels, 2) to achieve top arrangement for electrical generation for each locality. Table 5 reports the simulation of all feasible configurations of PV panels, diesel generators, batteries, and wind turbines. On the one hand, diesel generators can be the first appropriate option for remote rural areas where no grid electricity is available; on the other hand, heavy maintenance cost, fuel stock, and significant quantity of pollutants are most important barriers for diesel generator usage. In the second scenario, the energy of PV panels is transmitted to the controller, whereby batteries are charged. Meanwhile, low-voltage devices in DC are supplied through this power. $\mathrm{AC}$ converter is fed through battery and provides energy to the required high-voltage devices in $\mathrm{AC}$ [34]. In the third scenario, wind turbine is the energy provider in AC bus. Frankly speaking, this energy would convert to DC energy where batteries would use their required power. Obviously, for suppling high voltage energy consumer devices in $\mathrm{AC}$ bus batteries should transfer energy to AC converter.

Collecting power from various energy sources is the most significant advantage of hybrid energy systems. One single resource may not be adequate to fulfil peak energy demand throughout a year, especially during warm months of summer and cold months of winter. Accordingly, hybrid energy systems are the best candidate for this subject. The fourth scenario is the first hybrid configuration. In this configuration, wind turbine and PV panels provide energy to the hybrid system. 
Table 5 All feasible arrangement of wind turbines, batteries, diesel generators, and PV panels
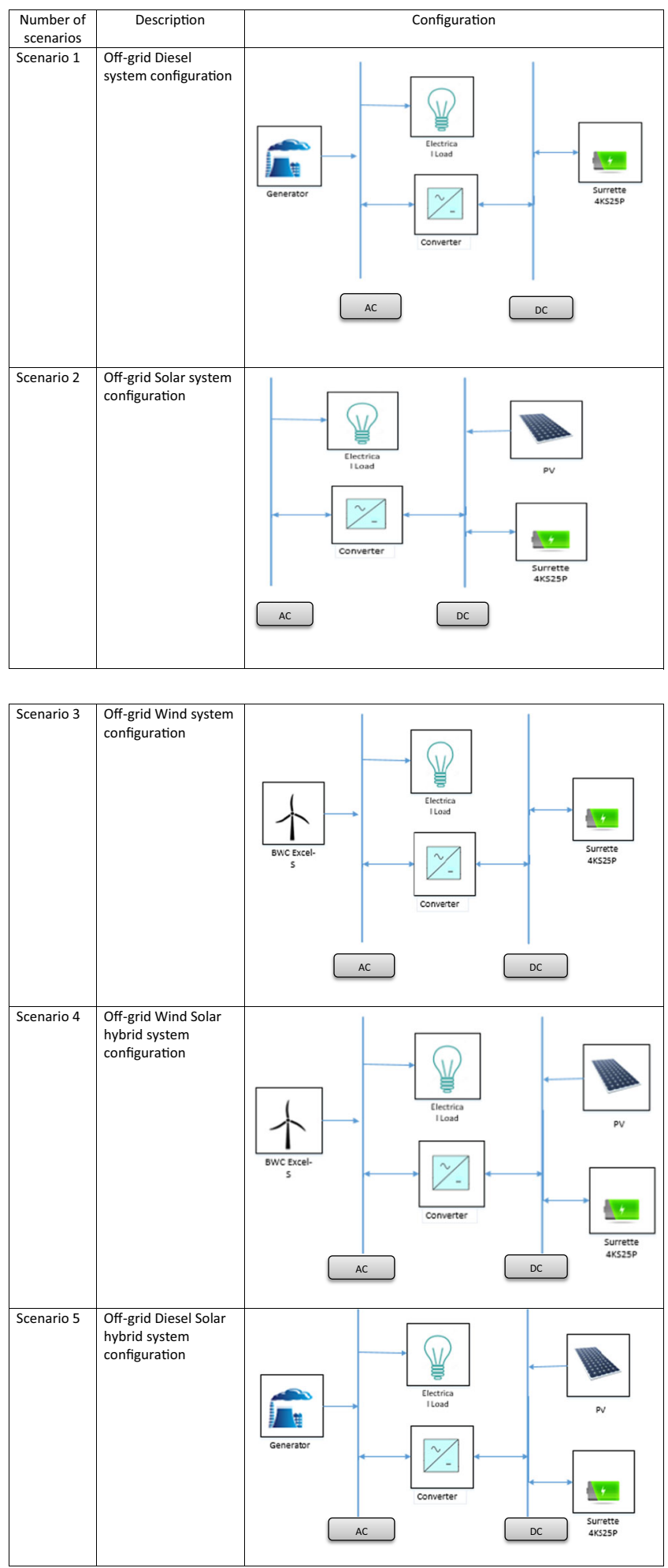

Further, one battery is applied as energy storage. Although the main function of battery bank is the storage of energy, during less sunny and windy days, this energy is feeding back to hybrid system. In the fifth and sixth scenario, diesel
Table 5 (continued)

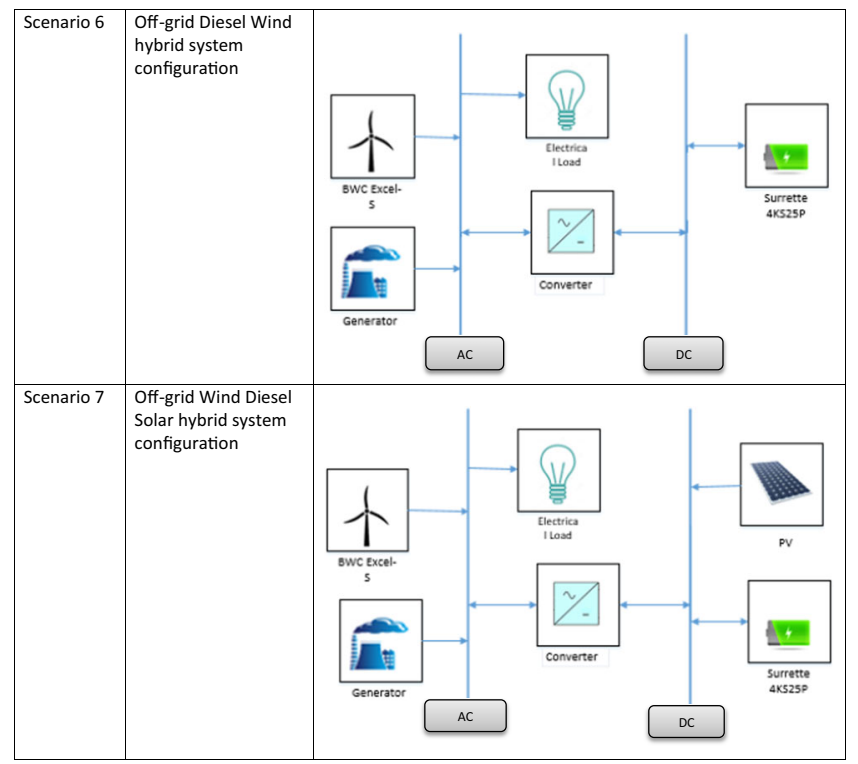

generator/PV panel and wind turbine/diesel generator provide energy to the hybrid energy system respectively. Although diesel generator can provide the entire peak and typical energy demand by itself, economic characteristic has been the main objective in this study. In the end, scenario seven is developed with wind turbine, photovoltaic, battery, and diesel generator. By adding diesel generator, feasible constant power would be guaranteed, though economic constraints of the system should still be considered.

\section{Results and Discussion}

With simulation of scenarios 1 to 7 for each village, the optimal configuration outcomes were obtained as presented in Tables 6, 7, 8, 9, 10 and 11. Environmentally, the results of $\mathrm{CO} 2$ emissions obtained are shown in the following tables. Yearly produced electrical power for each energy generator is also determined. A number of scenarios can satisfy the required electrical load by $100 \%$ renewable energy. However, in order to find the most economically suitable case, the most significant economic indicators namely operating cost $(\$ / y r)$, COE (\$/kWh), initial capital $(\$)$, and total NPC (\$) need to be examined.

\section{Optimal Design for Selected Communities}

\section{Optimal Design for Yaralujeh}

As Table 6 indicates, case 7 has resulted in the best design owning to the lowest NPC value for Yaralujeh. The 
Table 6 optimal design result for proposed configuration in Yaralujeh

Yaralujeh

\begin{tabular}{|c|c|c|c|c|c|c|c|}
\hline & Case 1 & Case 2 & Case 3 & Case 4 & Case 5 & Case 6 & Case 7 \\
\hline PV (KW) & - & 300 & - & 10 & 18 & - & 10 \\
\hline WT & - & - & 54 & 45 & - & 45 & 18 \\
\hline $\mathrm{G}(\mathrm{KW})$ & 63 & - & - & - & 54 & 10 & 54 \\
\hline Battery & 45 & 400 & 300 & 300 & 99 & 300 & 63 \\
\hline Converter(KW) & 18 & 81 & 72 & 72 & 27 & 63 & 27 \\
\hline Initial Capital(\$) & 66,294 & 929,810 & 293,161 & 293,521 & 128,369 & 266,151 & 148,246 \\
\hline Operating $\operatorname{Cost}(\$ / y r)$ & 32,926 & 25,858 & 18,367 & 17,996 & 28,729 & 17,684 & 15,717 \\
\hline Total NPC(\$) & 487,204 & $1,260,368$ & 527,956 & 523,570 & 495,624 & 492,213 & 349,167 \\
\hline $\operatorname{COE}(\$ / k w h)$ & 0.280 & 0.724 & 0.303 & 0.301 & 0.285 & 0.283 & 0.201 \\
\hline Ren. Frac. & 0 & 1 & 1 & 1 & 0.16 & 0.99 & 0.80 \\
\hline Diesel(L) & 57,036 & - & - & - & 44,778 & 963 & 20,281 \\
\hline $\mathrm{G}(\mathrm{hrs})$ & 3899 & - & - & - & 2760 & 366 & 1750 \\
\hline $\mathrm{PV}(\mathrm{kwh} / \mathrm{yr})$ & - & 405,002 & - & 13,500 & 24,300 & - & 13,500 \\
\hline WT(kwh/yr) & - & - & 573,594 & 477,996 & - & 477,996 & 191,198 \\
\hline DG(kwh/yr) & 149,542 & - & - & - & 131,419 & 2679 & 50,882 \\
\hline $\mathrm{Co}_{2}$ emission & 150,196 & 0 & 0 & 0 & 117,916 & 2535 & 53,406 \\
\hline
\end{tabular}

optimal size of the system for case 7 is $10 \mathrm{~kW} \mathrm{PV}$ panels, BWC Excel-S $18 \mathrm{~kW}$ wind turbine, $54 \mathrm{~kW}$ diesel generator, 63 Surrette $4 \mathrm{ks} 25 \mathrm{p}$ batteries, and $27 \mathrm{~kW}$ converter. This design leads to an initial capital of $148,246 \$$, an operating cost of $15,717 \$ / \mathrm{yr}$, total NPC of $349,167 \$$, and COE of $0.201 \$ / \mathrm{kwh}$.

\section{Optimal Design for Yanbolaghiye Sofla}

The environmental and economic results for Yanbolaghiye Sofla are outlined in Table 7. As shown in Table 7, among other cases, case 2 is the worst system configuration due to highest NPC value and cost of energy. Additionally, case 6 is

Table 7 optimal design result for proposed configuration in Yanbolaghiye Sofla

Yanbolaghiye Sofla

\begin{tabular}{|c|c|c|c|c|c|c|c|}
\hline & Case 1 & Case 2 & Case 3 & Case 4 & Case 5 & Case 6 & Case 7 \\
\hline $\mathrm{PV}(\mathrm{KW})$ & - & 200 & - & 10 & 18 & - & 10 \\
\hline WT & - & - & 45 & 36 & - & 18 & 18 \\
\hline $\mathrm{G}(\mathrm{KW})$ & 54 & - & - & - & 45 & 45 & 36 \\
\hline Battery & 36 & 300 & 200 & 200 & 72 & 45 & 63 \\
\hline Converter(KW) & 9 & 63 & 54 & 54 & 18 & 18 & 18 \\
\hline Initial Capital(\$) & 50,173 & 636,950 & 225,661 & 226,021 & 107,546 & 104,774 & 129,076 \\
\hline Operating $\operatorname{Cost}(\$ / y r)$ & 24,455 & 18,931 & 13,185 & 12,814 & 18,490 & 10,163 & 9543 \\
\hline Total NPC(\$) & 362,786 & 878,953 & 394,208 & 389,822 & 343,916 & 234,689 & 251,069 \\
\hline $\mathrm{COE}(\$ / \mathrm{kwh})$ & 0.311 & 0.754 & 0.338 & 0.334 & 0.295 & 0.201 & 0.215 \\
\hline Ren. Frac. & 0 & 1 & 1 & 1 & 0.24 & 0.87 & 0.90 \\
\hline Diesel(L) & 42,259 & - & - & - & 27,956 & 12,365 & 9501 \\
\hline $\mathrm{G}(\mathrm{hrs})$ & 3893 & - & - & - & 2238 & 1374 & 1269 \\
\hline $\mathrm{PV}(\mathrm{kwh} / \mathrm{yr})$ & - & 280,279 & - & 14,014 & 25,225 & - & 14,014 \\
\hline WT(kwh/yr) & - & - & 517,707 & 414,165 & - & 207,082 & 207,082 \\
\hline $\mathrm{DG}(\mathrm{kwh} / \mathrm{yr})$ & 101,767 & - & - & - & 79,596 & 29,676 & 23,386 \\
\hline $\mathrm{Co}_{2}$ emission $(\mathrm{kg} /$ year $)$ & 111,283 & 0 & 0 & 0 & 73,616 & 32,562 & 25,020 \\
\hline
\end{tabular}


Table 8 optimal design result for proposed configuration in Seyah Dowlan, Ahar

Seyah Dowlan, Ahar

\begin{tabular}{|c|c|c|c|c|c|c|c|}
\hline & Case 1 & Case 2 & Case 3 & Case 4 & Case 5 & Case 6 & Case 7 \\
\hline PV (KW) & - & 400 & - & 10 & 10 & - & 10 \\
\hline WT & - & - & 54 & 54 & - & 18 & 27 \\
\hline $\mathrm{G}(\mathrm{KW})$ & 72 & - & - & - & 72 & 54 & 54 \\
\hline Battery & 36 & 400 & 300 & 300 & 90 & 81 & 54 \\
\hline Converter(KW) & 18 & 90 & 81 & 72 & 27 & 27 & 27 \\
\hline Initial Capital(\$) & 69,343 & $1,188,180$ & 301,531 & 318,161 & 116,818 & 127,948 & 170,535 \\
\hline Operating Cost $(\$ / y r)$ & 37,627 & 28,710 & 18,868 & 18,602 & 36,090 & 16,711 & 14,420 \\
\hline Total NPC(\$) & 550,337 & $1,555,195$ & 542,724 & 555,962 & 578,172 & 341,575 & 354,873 \\
\hline $\mathrm{COE}(\$ / \mathrm{kwh})$ & 0.274 & 0.773 & 0.270 & 0.276 & 0.288 & 0.170 & 0.176 \\
\hline Ren. Frac. & 0 & 1 & 1 & 1 & 0.07 & 0.84 & 0.92 \\
\hline Diesel(L) & 66,086 & - & - & - & 59,294 & 21,444 & 17,209 \\
\hline $\mathrm{G}(\mathrm{hrs})$ & 4162 & - & - & - & 3246 & 1758 & 1657 \\
\hline $\mathrm{PV}(\mathrm{kwh} / \mathrm{yr})$ & - & 512,553 & - & 12,814 & 12,814 & - & 12,820 \\
\hline WT(kwh/yr) & - & - & 867,143 & 867,143 & - & 289,048 & 433,572 \\
\hline DG(kwh/yr) & 168,452 & - & - & - & 12,814 & 55,398 & 40,202 \\
\hline $\mathrm{CO}_{2}$ emission(kg/year) & 174,027 & 0 & 0 & 0 & 156,140 & 56,469 & 45,317 \\
\hline
\end{tabular}

selected as the most economical design, meeting environmental and economic targets, by offering the lowest NPC value. Although NPC value in case 7 for Yanbolaghiye Sofla is close to case 6 NPC value, case 7 presents a renewable fraction of 0.90 which is more preferable than case 6 . Accordingly, case 7 was chosen as the most appropriate design in terms of economic and environmental aspect for Yanbolaghiye Sofla. The optimal size of the system for case 7 is $10 \mathrm{~kW}$ PV panels, BWC Excel-S $18 \mathrm{~kW}$ wind turbine, $36 \mathrm{~kW}$ diesel generator, and 63 Surrette $4 \mathrm{ks} 25 \mathrm{p}$ batteries. This configuration leads to the initial capital of $129,076 \$$, operating cost of $9543 \$ / y$, total NPC of $251,069 \$$, and cost of energy of 0.215 .

Table 9 optimal design result for proposed configuration in Azarshahr railway station

Azarshahr railway station

\begin{tabular}{|c|c|c|c|c|c|c|c|}
\hline & Case 1 & Case 2 & Case 3 & Case 4 & Case 5 & Case 6 & Case 7 \\
\hline PV (KW) & - & 200 & - & 27 & 27 & - & 10 \\
\hline WT & - & - & 45 & 45 & - & 27 & 18 \\
\hline $\mathrm{G}(\mathrm{KW})$ & 54 & - & - & - & 54 & 45 & 45 \\
\hline Battery & 63 & 400 & 300 & 200 & 72 & 45 & 72 \\
\hline Converter(KW) & 18 & 81 & 63 & 63 & 27 & 18 & 27 \\
\hline Initial Capital(\$) & 65,596 & 679,810 & 260,151 & 301,531 & 143,816 & 129,415 & 145,197 \\
\hline Operating Cost(\$/yr) & 27,987 & 23,507 & 17,260 & 14,320 & 21,830 & 13,703 & 13,708 \\
\hline Total NPC(\$) & 423,359 & 980,308 & 480,796 & 484,592 & 422,871 & 304,587 & 320,434 \\
\hline $\mathrm{COE}(\$ / \mathrm{kwh})$ & 0.291 & 0.674 & 0.330 & 0.333 & 0.290 & 0.209 & 0.220 \\
\hline Ren. Frac. & 0 & 1 & 1 & 1 & 0.29 & 0.84 & 0.80 \\
\hline Diesel(L) & 47,143 & - & - & - & 32,998 & 17,717 & 15,888 \\
\hline G(hrs) & 3337 & - & - & - & 2244 & 1999 & 1576 \\
\hline $\mathrm{PV}(\mathrm{kwh} / \mathrm{yr})$ & - & 286,645 & - & 38,697 & 38,697 & - & 14,332 \\
\hline WT(kwh/yr) & - & - & 374,227 & 374,227 & - & 224,536 & 149,690 \\
\hline DG(kwh/yr) & 130,907 & - & - & - & 93,215 & 42,083 & 40,857 \\
\hline $\mathrm{Co}_{2}$ emission(kg/year) & 124,142 & 0 & 0 & 0 & 86,895 & 46,654 & 41,838 \\
\hline
\end{tabular}


Table 10 optimal design result for proposed configuration in Sari Bolagh, East Azerbaijan

Sari Bolagh, East Azerbaijan

\begin{tabular}{|c|c|c|c|c|c|c|c|}
\hline & Case 1 & Case 2 & Case 3 & Case 4 & Case 5 & Case 6 & Case 7 \\
\hline PV (KW) & - & 400 & - & 10 & 10 & - & 10 \\
\hline WT & - & - & 72 & 63 & - & 27 & 27 \\
\hline $\mathrm{G}(\mathrm{KW})$ & 72 & - & - & - & 81 & 63 & 54 \\
\hline Battery & 27 & 400 & 300 & 300 & 27 & 72 & 99 \\
\hline Converter(KW) & 18 & 90 & 81 & 81 & 9 & 36 & 36 \\
\hline Initial Capital(\$) & 66,992 & $1,188,180$ & 350,812 & 351,171 & 89,022 & 164,007 & 190,659 \\
\hline Operating Cost $(\$ / y r)$ & 39,473 & 28,710 & 20,081 & 19,709 & 39,381 & 16,031 & 15,382 \\
\hline Total NPC(\$) & 571,586 & $1,555,195$ & 607,509 & 603,122 & 592,443 & 368,939 & 387,299 \\
\hline $\mathrm{COE}(\$ / \mathrm{kwh})$ & 0.261 & 0.711 & 0.278 & 0.276 & 0.271 & 0.169 & 0.177 \\
\hline Ren. Frac. & 0 & 1 & 1 & 1 & 0.07 & 0.91 & 0.92 \\
\hline Diesel(L) & 70,132 & - & - & - & 69,834 & 18,725 & 15,230 \\
\hline $\mathrm{G}(\mathrm{hrs})$ & 4323 & - & - & - & 4340 & 1466 & 1339 \\
\hline $\mathrm{PV}(\mathrm{kwh} / \mathrm{yr})$ & - & 512,553 & - & 12,814 & 12,814 & - & 12,814 \\
\hline WT(kwh/yr) & - & - & $1,156,191$ & $1,011,664$ & - & 433,572 & 433,572 \\
\hline DG(kwh/yr) & 180,925 & - & - & - & 166,845 & 45,344 & 37,783 \\
\hline $\mathrm{CO}_{2}$ emission(kg/year) & 184,680 & 0 & 0 & 0 & 183,897 & 49,308 & 40,107 \\
\hline
\end{tabular}

\section{Optimal Design for Seyah Dowlan, Ahar}

Economic results for Seyah Dowlan, Ahar are listed in Table 8. As already mentioned, the economic indicators in this research include cost of energy, operating cost, net present cost value, and initial capital cost. By reviewing economic indicators, among other cases, cases 1,3, 6 and 7 have been selected to be evaluated because of offering the lowest NPC value, COE value for Seyah Dowlan, Ahar. In this community, because of high wind speed, a greater part of electrical load is created by wind turbine. Among these four designs, case 7 results in the best design for Seyah Dowlan, Ahar because of its low NPC value, and allowable renewable fraction of 0.92 . In addition,

Table 11 optimal design result for proposed configuration in Zaker, East Azerbaijan

Zaker, East Azerbaijan

\begin{tabular}{|c|c|c|c|c|c|c|c|}
\hline & Case 1 & Case 2 & Case 3 & Case 4 & Case 5 & Case 6 & Case 7 \\
\hline PV (KW) & - & 200 & - & 10 & 18 & - & 10 \\
\hline WT & - & - & 63 & 54 & - & 18 & 18 \\
\hline $\mathrm{G}(\mathrm{KW})$ & 54 & - & - & - & 54 & 45 & 45 \\
\hline Battery & 54 & 400 & 200 & 200 & 63 & 36 & 36 \\
\hline Converter(KW) & 18 & 72 & 63 & 54 & 18 & 18 & 18 \\
\hline Initial Capital(\$) & 63,245 & 671,440 & 283,311 & 275,301 & 110,596 & 102,424 & 127,424 \\
\hline Operating $\operatorname{Cost}(\$ / y r)$ & 26,936 & 23,007 & 14,898 & 14,027 & 22,271 & 11,837 & 11,368 \\
\hline Total NPC(\$) & 407,579 & 965,540 & 473,761 & 454,607 & 395,292 & 253,744 & 272,746 \\
\hline $\mathrm{COE}(\$ / \mathrm{kwh})$ & 0.299 & 0.709 & 0.348 & 0.334 & 0.290 & 0.186 & 0.200 \\
\hline Ren. Frac. & 0 & 1 & 1 & 1 & 0.21 & 0.86 & 0.88 \\
\hline Diesel(L) & 45,621 & - & - & - & 35,467 & 16,019 & 14,692 \\
\hline $\mathrm{G}(\mathrm{hrs})$ & 3401 & - & - & - & 2729 & 1784 & 1685 \\
\hline $\mathrm{PV}(\mathrm{kwh} / \mathrm{yr})$ & - & 280,979 & - & 14,040 & 25,272 & - & 14,040 \\
\hline WT(kwh/yr) & - & - & 805,957 & 690,818 & - & 230,272 & 230,272 \\
\hline $\mathrm{DG}(\mathrm{kwh} / \mathrm{yr})$ & 123,716 & - & - & - & 94,713 & 38,388 & 34,506 \\
\hline $\mathrm{CO}_{2}$ emission(kg/year) & 120,136 & 0 & 0 & 0 & 93,397 & 42,184 & 38,690 \\
\hline
\end{tabular}


case 3 is the most sustainable design by attaining renewable fraction of 1 . Note that $\mathrm{Co}_{2}$ emissions for cases 1,6 , and 7 are $174,027 \mathrm{~kg} / \mathrm{yr}, 56,469 \mathrm{~kg} / \mathrm{yr}$, and $45,317 \mathrm{~kg} / \mathrm{yr}$ respectively. Case 1 offers the lowest $\mathrm{Co}_{2}$ emission, achieving renewable fraction of 0 which in any case follows environmental objectives. The optimal size of the system for case 7 for Seyah Dowlan, Ahar is $10 \mathrm{~kW}$ PV panels, $27 \mathrm{~kW}$ BWC Excel-S wind turbine, $54 \mathrm{~kW}$ diesel generator, and 54 Surrette $4 \mathrm{ks} 25 \mathrm{p}$ batteries. This configuration leads to initial capital of $170,535 \$$, operating cost of $14,420 \$ / y$, total NPC of $354,873 \$$, and COE of $0.176 \$ / \mathrm{kwh}$. Both cases 6 and 7 for Seyah Dowlan, Ahar have an excess of energy, though case 7 provides a higher excess level which is $318,202 \mathrm{kwh} / \mathrm{yr}$.

\section{Optimal Design for Azarshahr Railway Station}

The environmental and economical results for Azarshahr Railway Station are illustrated in Table 9. Based on this table, among other cases, cases 5, 6, and 7 have the lowest COE and total NPC value. Accordingly, these cases are the most economical configuration for Azarshahr Railway Station. As can be seen from Table 9, case 2 is the worst system design with the highest NPC and COE value of 980,308\$ and 0.674 $\$ /$ kwh respectively. As shown in Table 9, although the NPC value of case 7 is slightly more than that of case 6 , case 7 meets the environmental objectives with $\mathrm{Co}_{2}$ emissions of $41,838(\mathrm{~kg} / \mathrm{yr})$. The optimum size configuration of Case 7 is $10 \mathrm{~kW}$ PV panels, one $18 \mathrm{~kW}$ BWC Excel-S wind turbine, one $45 \mathrm{~kW}$ diesel generator, and 72 Surrette $4 \mathrm{ks} 25 \mathrm{p}$ batteries. This design leads to the initial capital of $145,197 \$$, operating cost of $13,708 \$ / y r$, total NPC of $320,434 \$$, and COE of $0.220 \$ / \mathrm{kwh}$.

\section{Optimal Design for Sari Bolagh, East Azerbaijan}

Table 10 presents the economic and environmental results for Sari Bolagh, East Azerbaijan. Among other cases, cases 1, 6, and 7 have been selected bringing about the lowest NPC and COE value. As can be seen from Table 10, a large part of electrical load is claimed by the wind turbine. Among these three designs, case 7 leads to the most economic and sustainable configuration owning to its high renewable fraction of 0.92 . Note that the annual $\mathrm{Co}_{2}$ emissions for cases 1,6 and 7 are $184,680 \mathrm{~kg} / \mathrm{yr}, 49,308 \mathrm{~kg} / \mathrm{yr}$, and 40,107 kg/yr respectively. The annual $\mathrm{CO}_{2}$ emission results suggest that case 7 is the most sustainable configuration among these three cases. The optimal size configuration for case 7 is $10 \mathrm{~kW}$ PV panels, one $27 \mathrm{~kW}$ BWC Excel-S wind turbine, one $54 \mathrm{~kW}$ diesel generator, and 99 Surrette $4 \mathrm{ks} 25 \mathrm{p}$ batteries. This design results in the initial capital of 190,659 , operating cost of $15,382 \$ / \mathrm{yr}$, total NPC $387299 \$$, and COE of $0.177 \$ / \mathrm{kwh}$. Although case s1 and 6 have annual excess of energy, case 7 provides higher excess energy of about 296,043 kwh/yr. This excess energy can be applied in case of population growth, additional energy activities, probability of selling to environs villages, given the village's geographical circumstances. Overall, case 7 is chosen as the most sustainable configuration for Sari Bolagh, East Azerbaijan.

\section{Optimal Design for Zaker, East Azerbaijan}

Table 11 reports the economic and environmental results for Zaker, East Azerbaijan. One important note, interpreted from Table 11, is that case 2 (PV panel) is the worst system configuration from an economic viewpoint because of its higher initial capital of $671,440 \$$. Another remarkable note, from Table 11, is that in cases 3,4 , and 7 , the crucial part of electrical load is claimed by wind turbine with case 7 being the most feasible design among all other cases with the lowest $\mathrm{CO}_{2}$ emission of $38,690 \mathrm{~kg} / \mathrm{yr}$. Note that, among other cases, case 7 meets environmental and economic goals by lowest NPC and cost of energy value. The optimal size configuration for case 7 is $10 \mathrm{~kW}$ PV panels, one $18 \mathrm{~kW}$ BWC Excel-S wind turbine, one $45 \mathrm{~kW}$ diesel generator, and 36 Surrette $4 \mathrm{ks} 25 \mathrm{p}$ batteries. This design leads to initial capital of $127,424 \$$, operating cost of 11,368 $\$ / y r$, total NPC of 272,746 , and cost of energy of $0.20 \$ / \mathrm{kwh}$.

Figure 6 (a) - (b) show the electricity distribution details for cases 4 and 7 respectively. Yellow, green, and black bars represent the power produced by PV panels, wind turbine, and diesel generator. Cases 4 shows that the monthly electricity generation is in parallel with monthly electricity utilization. However, because of irregular nature of renewable resources, an alteration in the mean generated power can be observed [35]. Since the power produced through $\mathrm{PV}$ panels is a slight part of the entire produced power, for electricity generation in this study, applying wind turbine is more economically justified than using PV panels. However, at high levels of generation, PV panels can be economically competitive [36]. Although diesel configuration is the cost-effective option in the short period of time due to the remarkably low fuel price in Iran, wind turbine is influential system design in the long term. Generally, case 7 is chosen as the most economic and sustainable configuration for Zaker, East Azerbaijan, meaning the lowest $\mathrm{Co}_{2}$ emission as well as low NPC and cost of energy. Indeed, in turn, it means high capital recovery factor, and thus high recovery on economic indicators. 


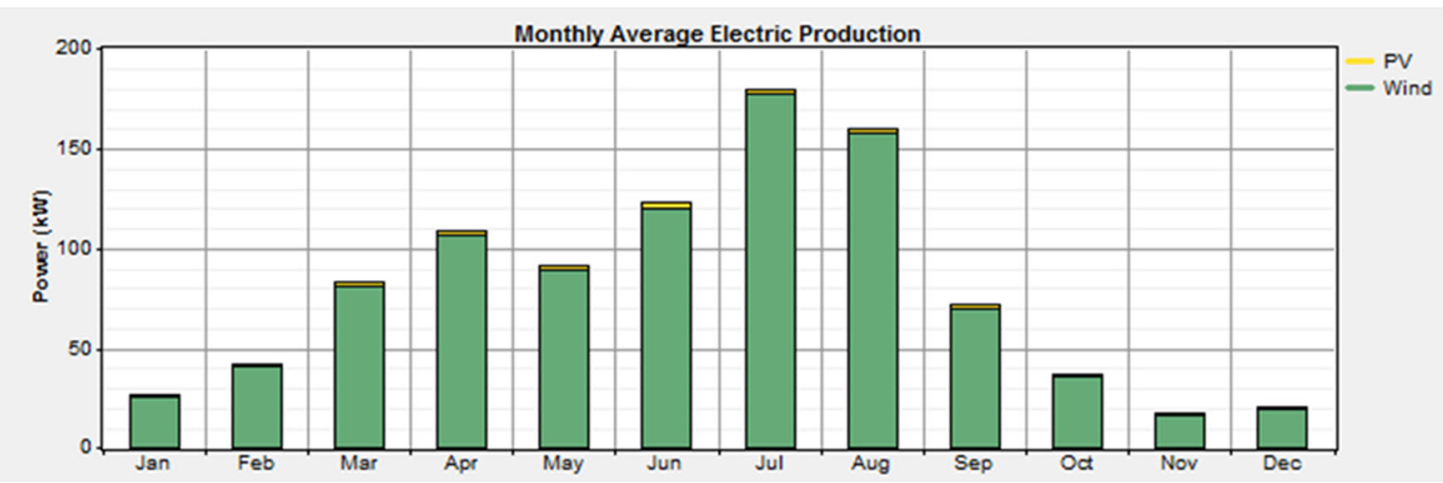

(a)

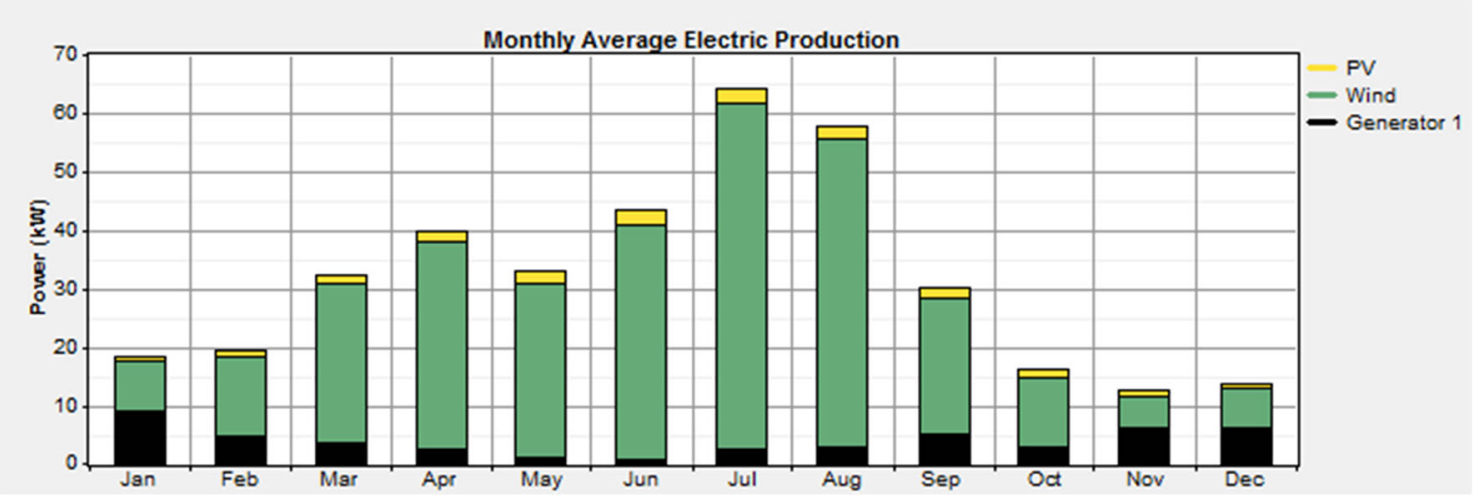

(b)

Fig. 6 a-b - yearly electricity production for case 4 and 7 in Zaker, East Azerbaijan

\section{Cost Breakdown for Components of the Selected Optimal Communities}

In this part, the cost breakdown for selected optimal configuration in the previous section is described in more detail. The entire cost of each configuration generally comprises the capital cost, replacement cost, operating cost, fuel cost, as well as salvage cost.

The cost breakdown for Case 7 for Yaralujeh is revealed in Fig. 7(a). As can be seen in this figure, the largest cost is attributed to the system capital cost. Remember that BWC Excel-S wind turbine conduces $34 \%$ of the capital cost of system where contribute $18.5 \%$ of total cost of system.

Figure 7(b) displays the final cost of components for case 7 for Yanbolaghi-ye Sofla which is the best configuration based upon economic and environmental aspects. As can be easily interpreted, wind turbine claims the largest part of capital and replacement cost, with PV panels being the second most expensive component of the capital cost of the system following wind turbine. The wind turbine claims $38 \%$ and $38.5 \%$ of capital and replacement costs of the system respectively. Another significant note is that PV panels constitute almost $20 \%$ of the capital cost of the system. Finally, the capital cost contributes to $51 \%$ of the total cost of the system.
The cost breakdown for case 7 for Seyah Dowlan, Ahar is illustrated in Fig. 7(c). Note that capital cost the largest component economically. It can be seen that wind turbine claims $46.5 \%$ of replacement cost and $43 \%$ of capital cost, accounting for $27 \%$ of the total cost of system.

Figure 7(d) demonstrates the cost breakdown for Azarshahr Railway Station. The priciest component of the system is BWC Excel-S wind turbine, claiming 34\% of capital and replacement cost of system and $20.5 \%$ of total cost of system. Obviously, the replacement cost associated with diesel generators is zero.

Figure 7(e) shows the cost breakdown for case 7 for Sari Bolagh, East Azerbaijan. Furthermore, Note that capital cost is the most expensive portion of the system's total cost followed by replacement and operating costs respectively. Meanwhile, BWC Excel-S wind turbine claims almost $39 \%$ of the capital and replacement cost of system and $25 \%$ of the total cost of system.

Eventually, Fig. 7(f) indicates cost breakdown for case 7 for Zaker, East Azerbaijan. Based on this figure, BWC Excel-S wind turbine constitutes the major part of capital cost and system total cost, followed by replacement and operating costs for the total cost. Wind turbine constitutes $39 \%$ of the capital cost of the system. Finally, wind turbine claims $43.5 \%$ and $21 \%$ of replacement and operating costs of the system respectively. 


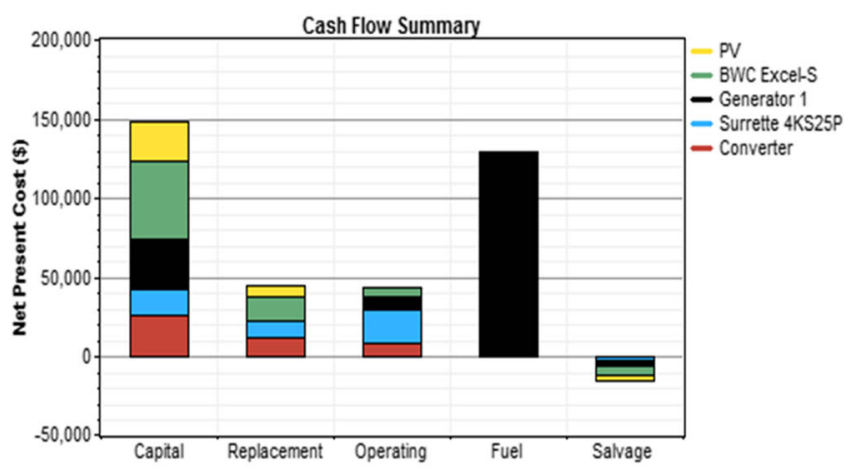

(a)

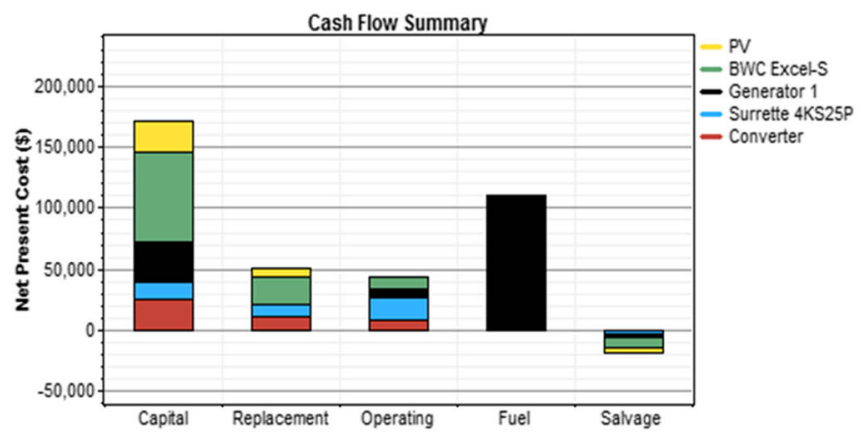

(c)

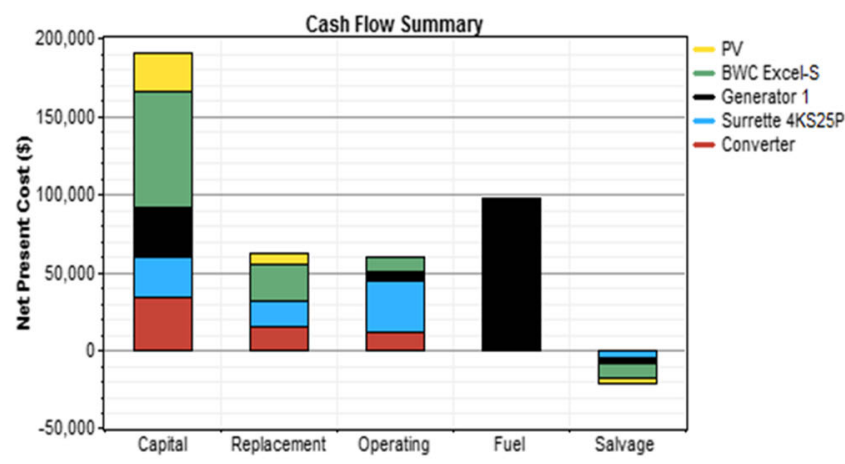

(e)

Fig. 7 a - f - cost breakdown for proposed configurations.

\section{Conclusion and Future Works}

This research dealt with the techno-economic and environmental assessment of various off-grid designs in six remote rural areas in East Azerbaijan province, Iran. In this study, all possible configurations of wind turbines, PV panels, and diesel generators were modeled and analyzed. In order to find the most suitable system design from economic, technical, and environmental viewpoints, HOMER software was applied. For the geographical map and economic model, Arc GIS and Visio software were used. Net present cost, COE, initial capital cost, and operating cost were considered as economic indicators, while yearly $\mathrm{CO} 2$ emission designated the most significant indicator for sustainable prospective. Hybrid renewable energy systems were the most convenient

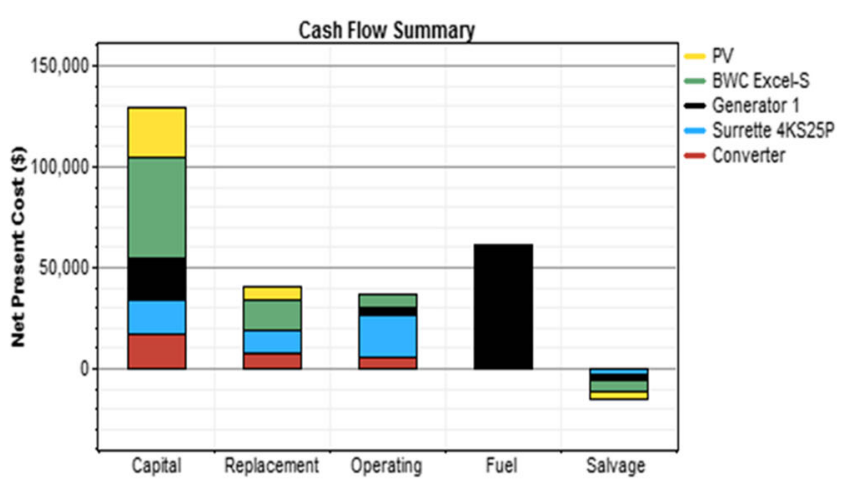

(b)

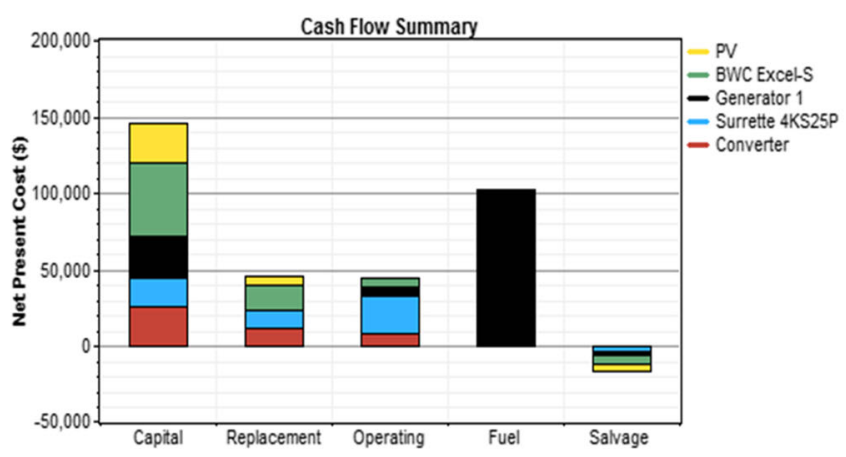

(d)

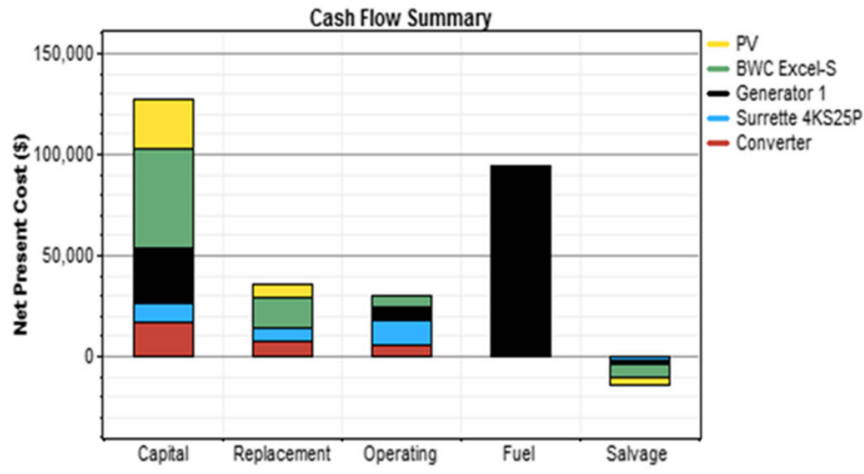

(f)

configurations from environmental and economic viewpoints, though remarkably high expenses are the main trouble reducing the installation possibility of these configurations in the proposed communities. Apart from the necessary initial investment, application of these areas results in high operational costs which obviously cannot be paid by the low-income communities. The Iran's government can play a remarkable role for facilitating the application of renewable energy systems for remote rural areas. The current renewable energy system expansion support policies include tax reductions and exemptions, which is not enough for low-income communities. In case sufficient support policies are provided by the government, optimal proposed sizes can be applied to provide electricity to the communities in an economically and environmentally suitable way. Future 
work will investigate two directions. First, studies should profoundly evaluate renewable energy systems considering technical, environmental, social, and economic indicators all together. On the other hand, new methods can be applied by expanding case studies to the entire country or even by considering social, economic, technical, and environmental indicators for different countries.

\section{Compliance with Ethical Standards}

Declaration of Interest Statement The author declare that he does not have known competing financial interests or personal relationships that could have appeared to influence the work reported in this paper. In short, the author declare he does not have conflict of interest.

Nomenclature RES, Renewable energy systems; DG, Diesel generator; PV, Photovoltaic; Ren. Frac., Renewable fraction; WT, Wind turbine; COE, Cost of energy; NPC, Net present cost; SHS, Solar home system; Biogas G, Biogas generator; EV, Electric Vehicle; FC, Fuel cell

\section{References}

1. Al-Mansour F, Sucic B, Pusnik M (2014) Challenges and prospects of electricity production from renewable energy sources in Slovenia. Energy 77:73e81

2. Garcia-Heller VR, Paredes S (2016) Forecast study of the supply curve of solar and wind technologies in Argentina, Brazil, Chile and Mexico. Renew Energy 93:168-179

3. Amir Kordvani, Munir Hassan, Louise Dalton, Poulad Berenjforoush, Renewable Energy in Iran, cms-lawnow.com

4. International Energy Agency. http://www.iea.org/statistics

5. British Petroleum (BP) Statistical Review of World Energy (2014). Available from: <http://www.bp.com/statisticalreview\#BPstats>

6. Khan MJ, Yadav AK, MatheW L (2017) Techno economic feasibility analysis of different combinations of PV-WindDiesel-Battery hybrid system for telecommunication applications I different cities of Punjab, India. Renew Sust Energ Rev 76:577-607

7. Zelalem Girma (2016) Techno-economic feasibility of small scale hydropower in Ethiopia: The Case of the Kulfo River, in Southern Ethiopia, Hindawi Publishing Corporation. Journal of Renewable Energy, Volume 2016, Article ID 8037892, 12 pages

8. Karakoulidis K, Mavridis K, Bandekas DV, Adoniadis P, Potolias C, Vordos N (2011) Techno-economic analysis of a stand-alone hybrid photovoltaic-dieselebattery-fuel cell power system. Renew Energy 36:2238-2244

9. Ramli MAM, Hiendro A, Al-Turki YA (2016) Techno-economic energy analysis of wind/solar hybrid system: Case study for western coastal area of Saudi Arabia. Renew Energy 91:374-385

10. Kalinci Y, Hepbasli A, Dincer I (2014) Techno-economic analysis of a stand-alone hybrid renewable energy system with hydrogen production and storage options. Int J Hydrog Energy XXX:1-13

11. Ghasemi A, Asrari A, Zarif M, Abdelwahed S (2013) Technoeconomic analysis of stand-alone hybrid photovoltaic-diesel-battery systems for rural electrification in eastern part of Iran-A step toward sustainable rural development. Renew Sust Energ Rev 28: 456-462

12. Akinbulire TO, Oluseyi PO, Babatunde OM (2014) Technoeconomic and environmental evaluation of demand side management techniques for rural electrification in Ibadan, Nigeria. Int $\mathrm{J}$ Energy Environ Eng 5:375-385
13. Khalid F, Dincer I, Rosen MA (2016) Techno-economic assessment of a renewable energy based integrated multigeneration system for green buildings. Appl Therm Eng 99:1286-1294

14. Taliotis C, Taibi E, Howells M, Rogner H, Bazilian M, Welsch M (2017) Technoeconomic assumptions adopted for the development of a long-term electricity supply model for Cyprus. Data in Brief 14: 730-737

15. Baneshi M, Hadianfard F (2016) Techno-economic feasibility of hybrid diesel/PV/wind/battery electricity generation systems for non-residential large electricity consumers under southern Iran climate conditions. Energy Convers Manag 127:233-244

16. Bhattacharjee S, Dey A (2014) Techno-economic performance evaluation of grid integrated PV-biomass hybrid power generation for rice mill. Sustainable Energy Technologies and Assessments 7: 6-16

17. Kolhe ML, Ranaweera KMIU, Gunawardana AGBS (2015) Techno economic sizing of off-grid hybrid renewable energy system for rural electrification in Sri Lanka. Sustainable Energy Technologies and Assessments 11:53-64

18. Barun K. Das, Najmul Hoque, Soumya Mandal, Tapas Kumar Pal, Md Abu Raihan, A techno-economic feasibility of a stand-alone hybrid power generation for remote area application in Bangladesh. Energy S0360-5442(17)31016-2

19. Ramin Hosseinalizadeh, Elahe sadat Rafiei, Ali Shafiei Alavijeh, Seyed Farid Ghaderi (2017) Economic analysis of small wind turbines in residential energy sector in Iran. Sustainable Energy Technologies and Assessments 20: 58-71

20. Fazelpour F, Soltani N, Rosen MA (2016) Economic analysis of standalone hybrid energy systems for application in Tehran, Iran. Int J Hydrog Energy 41:7732-7743

21. Grande LSA, Yahyaoui I, Gómez SA (2018) Energetic, economic and environmental viability of off-grid PV-BESS for charging electric vehicles: Case study of Spain. Sustain Cities Soc 37:519-529

22. Al-Sharafi A, Sahin AZ, Ayar T, Yilbas BS (2017) Technoeconomic analysis and optimization of solar and wind energy systems for power generation and hydrogen production in Saudi Arabia. Renew Sust Energ Rev 69:33-49

23. M. Kashif Shahzad, Adeem Zahid, Tanzeel ur Rashid, Mirza Abdullah Rehan, Muzaffar Ali, Mueen Ahmad, Techno-economic feasibility analysis of a solar-biomass off grid system for the electrification of remote rural areas in Pakistan using HOMER software. Renewable Energy S0960-1481(17)30041-1

24. Monotosh Das, Maisanam Anil Kumar Singh, Agnimitra Biswas, Techno-economic optimization of an off-grid hybrid renewable energy system using metaheuristic optimization approaches - Case of a radio transmitter station in India, Energy Conversion and Management Pages 339-352

25. A. Can Duman, Önder Güler, Techno-economic analysis of off-grid $\mathrm{PV} /$ wind/fuel cell hybrid system combinations with a comparison of regularly and seasonally occupied households, Sustainable Cities and Society Pages 107-126

26. Kolhe ML, Ranaweera KMIU, Gunawardana AGBS (2015) Techno-economic sizing of off-grid hybrid renewable energy system for rural electrification in Sri Lanka. Sustainable Energy Technologies and Assessments 11:53-64

27. Ghasemi A, Asrari A, Zarif M, Abdelwahe S (2013) Technoeconomic analysis of stand-alone hybrid photovoltaic-diesel-battery systems for rural electrification in eastern part of Iran - a step toward sustainable rural development. Renew Sust Energ Rev 28: 456-462

28. Nfah EM, Ngumdam JM, Tchinda R (2007) Modelling of solar/ diesel/battery hybrid power systems for far-North Cameroon. Renew Energy 32(5):832-844

29. Getting Started Guide for HOMER (2005) National Renewable Energy Laboratory 
30. Qolipour M, Mostafaeipour A, Tousi OM (2017) Techno-economic feasibility of a photovoltaic-wind power plant construction for electric and hydrogen production: A case study. Renew Sust Energ Rev $78: 113-123$

31. Mostafaeipour A, Qolipour M, Mohammadi K (2016) Evaluation of installing photovoltaic plants using a hybrid approach for Khuzestan province, Iran. Renew Sust Energ Rev 60:60-74

32. Qolipour M, Mostafaeipour A, Shamshirband SH, Alavi O, Goudarzi H, Petkovic D (2016) Evaluation of wind power generation potential using a three hybrid approach for households in Ardebil Province, Iran. Energy Convers Manag 118:295-305

33. Ameen AM, Pasupuleti J, Khatib T (2015) Simplified performance models of photovoltaic/diesel generator/battery system considering typical control strategies. Energy Convers Manag 99:313-325
34. Boxwell M (2013) Solar electricity handbook, 2013, pp. 24e25

35. Hafez O, Bhattacharya K (2012) Optimal planning and design of a renewable energy base supply system for microgrids. Renew Energy 45:7-15

36. The International Renewable Energy Agency (IRENA) (2012) Renewable energy technologies: cost analysis series - wind power, power sector $1(5 / 5): 18-34$

Publisher's Note Springer Nature remains neutral with regard to jurisdictional claims in published maps and institutional affiliations. 